\title{
LA CIUDAD CELESTE DE HILDEGARD VON BINGEN ${ }^{1}$
}

\author{
THE HEAVENLY CITY OF HILDEGARD VON BINGEN
}

\author{
VICTORIA CIRLOT \\ Universitat Pompeu Fabra
}

\begin{abstract}
Resumen: El artículo comienza con una introducción a la experiencia visionaria de Hildegard según se comprendía en el siglo XII, esto es, como una revelación y una inspiración del Espíritu Santo y por tanto como un acontecimiento que repite el suceso de Pentecostés. Se aborda seguidamente la visión de la ciudad celeste en la obra profética de la santa, en concreto, en Scivias y en Liber Divinorumoperum, en la poesía y en la correspondencia, para luego dar entrada a una comparación de esta visión de la ciudad con la visión de la Jerusalén celeste y su función y significado en la cultura medieval. Se concluye con un ejemplo de visión de la ciudad celeste en el siglo XX que proporciona el Libro Rojo de Carl Gustav Jung. Este último punto tiene como objetivo mostrar la supervivencia del tema en la cultura moderna aunque expresado en contextos y lenguajes muy diferentes.
\end{abstract}

Palabras clave: Visión; sueño; Espíritu Santo; ciudad celeste; Jerusalén celeste.

\begin{abstract}
The article begins with an introduction to Hildegard's visionary experience as understood in the twelfth century, that is, as a revelation and an inspiration of the Holy Spirit and therefore as an event that repeats the Pentecost event. It then considers the vision of the heavenly city in the saint's prophetic work, specifically in Scivias and Liber Divinorum operum, and in her poetry and correspondence, comparing this view of the city with the vision of the heavenly Jerusalem as its role and meaning were understood in medieval culture. We conclude with an example of the view of the heavenly city in the twentieth century provided by the Red Book of Carl Gustav Jung. This last point aims to show the survival of the subject in modern culture, albeit expressed in very different contexts and languages.
\end{abstract}

Keywords: vision; dream; Holy Spirit; heavenly city; heavenly Jerusalem.

\section{SUMARIO}

1. Experiencia visionaria y sueño.- 2. La visión de la ciudad celeste.- 3. Jerusalén celeste.-4. Simbolismo del mandala.- 5. Bibliografía citada.

1 El origen de este artículo fue una conferencia pronunciada en el seminario del profesor Carlo Ossola en el Collège de France el 6 de febrero de 2012. El artículo ha sido financiado por AGAUR (ref. 2009 SGR 1551) y por MINECO (ref. FF12010-16796). 
Las visiones constituyeron una extraña experiencia en la vida de Hildegard von Bingen. Le sucedieron desde su más tierna infancia, desde los tres años, y no le abandonaron nunca; le concedieron el carisma necesario para una posición privilegiada en su mundo e impulsaron la escritura. Su obra profética, que comenzó a escribir a la edad de cuarenta y dos años y siete meses, en el año 1141, fue configurada a partir de las visiones, primero descritas y luego interpretadas a partir de una exégesis alegórica. Pero no sólo la obra profética derivó de la experiencia visionaria, sino que ésta se encuentra también en el origen de sus composiciones musicales y poéticas (Symphonia harmoniae caelestium revelationum y Ordo virtutum), en sus experimentos lingüísticos (Lingua ignota y Litterae ignotae) y en muchas de las cartas que forman su gruesa correspondencia dirigida tanto a laicos como eclesiásticos, tanto a desconocidos como a grandes personajes de su época. Sólo su obra médica (Causae et curae) y la que trata sobre la naturaleza (Physica) parecen situarse al margen de la visión para dar paso a un agudo y penetrante sentido de la percepción, lo que constituye un interesante contrapunto en la compleja personalidad de la visionaria. Las visiones de Hildegard despliegan una cosmología en la que la potencia simbólica resulta palpable. Los miniaturistas que trasladaron sus visiones al pergamino siguieron con fidelidad sus descripciones, lo que dio como resultado imágenes nuevas dentro de un arte tradicional como lo era el de la segunda mitad del siglo XII y principios del siglo XIII. Como en un fresco gigantesco se van sucediendo las imágenes-símbolo en la obra de Hildegard, en Scivias (1141-1151) o en el Liber divinorum operum (1163-1173). Las visiones paradisíacas, representaciones del más allá, ocupan un lugar destacado en ambas obras. Se trata en ambos casos de la visión de una ciudad que puede identificarse con la Jerusalén celeste. El análisis de las ciudades simbólicas en la obra de Hildegard ya fue objeto de estudio por parte de Peter Dronke ${ }^{2}$. Pero en este artículo se aborda el tema desde una perspectiva distinta a la del gran estudioso de la obra hildegardiana. Me interesa especialmente el fenómeno de la visión que es el que ha conducido mis estudios sobre la mística y profeta del $\mathrm{Rin}^{3}$. Así pues, propongo una aproximación a la ciudad celeste de Hildegard von Bingen a partir de cuatro etapas: en una primera, trataré de abordar el fenómeno visionario para conceder un marco a ese suceso consistente en "ver la ciudad"; en una segunda, describiré las visiones de la ciudad celeste a partir de Scivias fundamentalmente, pero recurriendo también a cualquier pasaje que en su obra profética, poética o epistolar pueda ayudar a su comprensión; en una tercera, intentaré reflexionar sobre el valor de las imá-

2 P. Dronke, The Symbolic Cities, donde analizó las fuentes posibles de Hildegard (Apocalipsis, Pastor Hermas y La ciudad de Dios de san Agustín), pp. 168-174.

${ }^{3}$ V. Cirlot, Hildegard von Bingen y la tradición; eadem, La visión abierta. 
genes de la ciudad celeste según su contexto; y finalmente, en una cuarta, realizaré alguna comparación con la visión de la ciudad celeste en el siglo XX con el fin de ofrecer perspectiva histórica al caso Hildegard.

\section{EXPERIENCIA VISIONARIA Y SUEÑO}

En los manuscritos en los que se copiaron Scivias y el Liber divinorum operum Hildegard fue representada recibiendo la revelación divina. En el manuscrito de Scivias, actualmente perdido y del que sólo se conservan algunas fotografías y el facsímil realizado en el monasterio de Eibingen a finales de los años veinte de nuestro siglo, Hildegard aparece en el primer folio vestida como una monja benedictina, con las tablillas de cera y el punzón, dispuesta a escribir todo aquello que vea y oiga, tal y como le ordena la voz del cielo. Situada en el interior de un edificio, en un espacio que alude a la celda del monasterio, es observada atentamente por un monje que, transgrediendo los marcos arquitectónicos, se introduce en el espacio visionario (Fig.1).

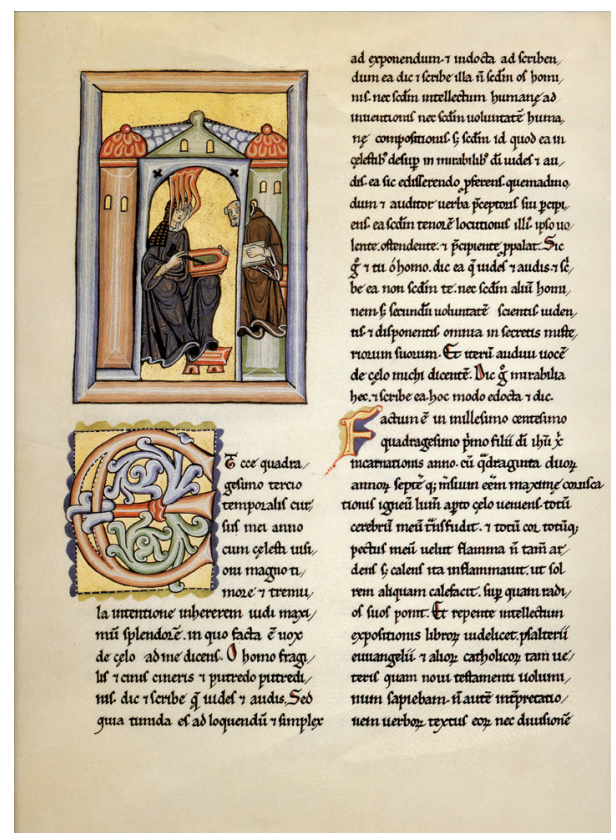

Fig. 1. Hildegard von Bingen, Scivias, facsímil de Eibingen a partir de Wiesbaden, Hessische Landesbibliothek, ms. 1 (perdido), f. 1r. 
Este personaje ha sido identificado con Volmar, el primer secretario de Hildegard, que le ayudó con la gramática y sintaxis latina. El suceso extraordinario se encuentra representado a partir de una especie de lenguas de fuego que penetran en su cerebro, ilustrando así la declaración de Hildegard ${ }^{4}$ :

Sucedió que, en el año 1141 de la Encarnación de Jesucristo Hijo de Dios, cuando cumplía yo cuarenta y dos años y siete meses de edad, del cielo abierto vino a mí una luz de fuego deslumbrante; inundó mi cerebro todo y, cual llama que aviva pero no abrasa, inflamó todo mi corazón y mi pecho, así como el sol calienta las cosas al extender sus rayos sobre ellas. Y, de pronto, gocé del entendimiento de cuanto dicen las Escrituras: los Salmos, los Evangelios y todos los demás libros católicos del Antiguo y Nuevo Testamento, aun sin poseer la interpretación de las palabras de sus textos, ni sus divisiones silábicas, casos o tiempos.

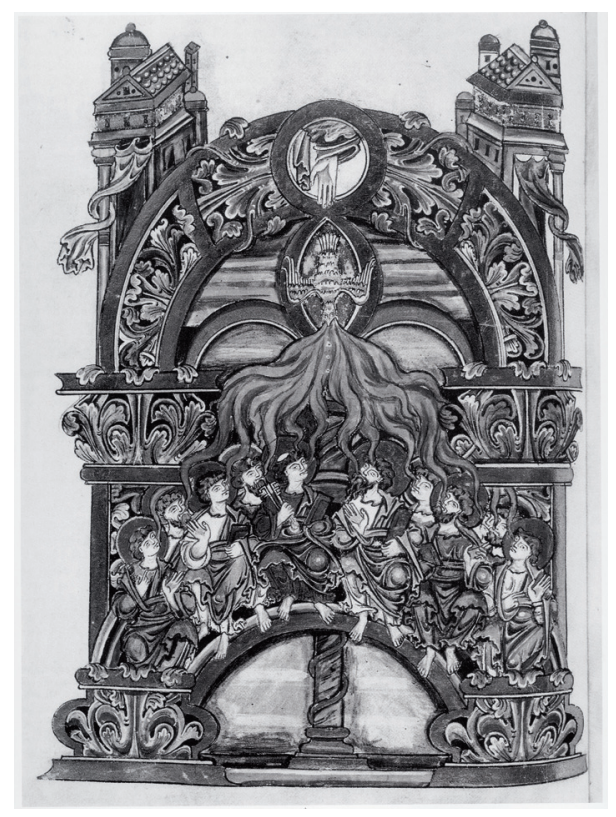

Fig. 2. Pentecostés, Rouen, Biblioteca Municipal, ms. Y 7, f. 29v.

${ }^{4}$ H. von Bingen, Scivias: conoce los caminos, pp. 15-16; Hildegardis Scivias. 
Este manuscrito (el Riesencodex, Wiesbaden, Hess. Landesbibliothek, Hs. 1), realizado en vida de Hildegard y con toda probabilidad bajo su supervisión en algún taller importante de la época dada la riqueza y la calidad de sus ilustraciones (Trier, Andernach, Maria Laach), nos ofrece el primer retrato de la visionaria según un modo muy cercano a cómo en aquellos mismos años se entendía el Pentecostés. En efecto, la iconografía del Pentecostés, los apóstoles sentados recibiendo las lenguas de fuego del Espíritu Santo (Fig. 2), proporcionó al artista del ms de Wiesbaden el modelo de comprensión para las palabras de Hildegard ${ }^{5}$.

La visionaria, como los apóstoles, estará ya en condiciones de marchar hasta los confines de la tierra para predicar la palabra recibida del Espíritu. En su caso se tratará fundamentalmente de escribir, en una estrecha relación, tal y como manifiesta la miniatura, entre inspiración del Espíritu, iluminación o visión y escritura. En esta misma situación la encontramos en el manuscrito que se conserva en la actualidad en la Biblioteca estatale de Lucca (Fig. 3), también de origen alemán, fechado en la primera mitad del siglo XIII,

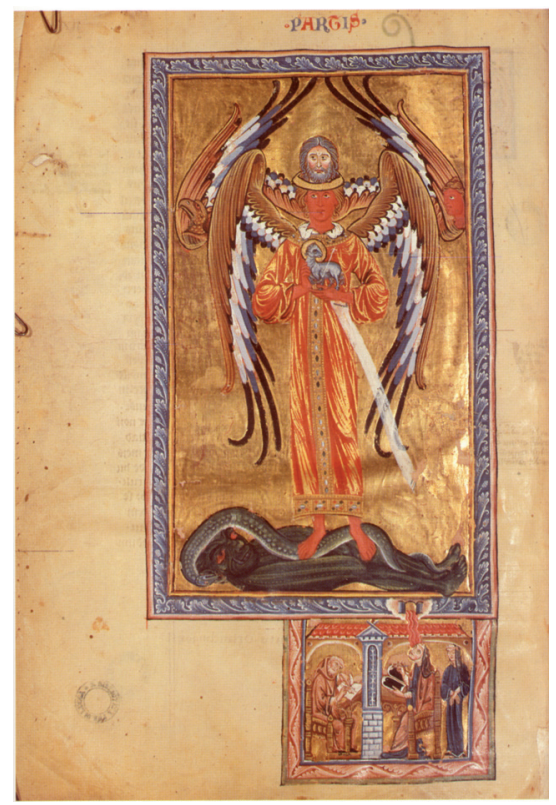

Fig. 3. Hildegard von Bingen, Liber divinorum operum,

Biblioteca estatal de Lucca, ms. L, 1942, f. 1v. Principios siglo XIII.

${ }^{5}$ L.E. Saurma-Jeltsch, Die Miniaturen, pp. 31-32. 
en que se copió el Liber Divinorum operum, la última de sus obras proféticas, iniciada en el año 1163, y que siguió al Liber vitae meritorum (1158-1163) que quedó sin ilustrar. El manuscrito de Lucca fue una obra realizada con la intención de promover la santificación de la visionaria, lo que nunca llegó a suceder, y de ahí el énfasis a la hora de mostrar la experiencia visionaria de Hildegard, pues ésta aparece no sólo en el primer folio del Liber, sino en todos los folios en que se representaron sus diez visiones ${ }^{6}$.

Esta insistencia se debe a la necesidad de dejar claro que toda la obra no es sino el resultado de la revelación divina, destacando el sujeto elegido por Dios para hablar a través de él. La voz de Hildegard sólo se oye, tanto en Scivias como en el Liber divinorum operum, para aludir a su experiencia, ego vidi et audivi, pero la voz que habla interpretando las visiones es la de Dios, de modo que ella carece de toda responsabilidad sobre el contenido de su obra. Aquí radica la diferencia fundamental entre Hildegard y las místicas del siglo XIII, pues mientras aquéllas escribían en primera persona, Hildegard es sólo transmisora, instrumento divino como dirá ella misma ${ }^{7}$. En el primer folio del manuscrito de Lucca (Fig. 3) es una ventana la que comunica con la tierra el mundo de las visiones, lo que con Henry Corbin podríamos denominar el mundus imaginalis ${ }^{8}$. Vemos a Hildegard en la celda de su monasterio en la que escribe, acompañada aquí de nuevo por su secretario Volmar y por una monja. Pero si hay algo que realmente resulta propio y específico de Hildegard y que además domina en ambas ilustraciones, la de Scivias y la del Liber, son sus ojos desmesuradamente abiertos, lo cual no es sino otra muestra de la fidelidad con que los miniaturistas trasladaron a imágenes sus textos. En diversos pasajes dentro de su obra profética, en los prólogos o epílogos, en algunas de sus cartas, en algunos pasajes autobiográficos que introdujo Theodorich von Echternach en la biografía que le dedicó pocos años después de su muerte en el año 1179, Hildegard repitió una y otra vez que jamás tuvo sus visiones en éxtasis, sino siempre despierta, y nunca en lugares apartados sino en lugares frecuentados ${ }^{9}$. Elijo uno de entre estos pasajes a modo de ejemplo, el de la Protestificatio de Scivias ${ }^{10}$ :

${ }^{6}$ Un completo estudio del manuscrito en: A.R. Calderoni Masetti, G. Dalli Regoli, Sanctae Hildegardis Revelationes.

7 P. Dronke, La escritoras de la Edad Media, p. 280.

${ }^{8}$ H. Corbin, Cuerpo espiritual, pp. 103-105.

9 Véase a este respecto, V. Cirlot, Hildegard von Bingen y la tradición, pp. 21-41.

${ }^{10} \mathrm{H}$. de Bingen, Scivias: conoce los caminos, p. 16. 
Mas las visiones que contemplé, nunca las percibí ni durante el sueño, ni en el reposo, ni en el delirio. Ni con los ojos de mi cuerpo, ni con los oídos del hombre exterior, ni en lugares apartados. Sino que las he recibido despierta, absorta con la mente pura, con los ojos y oídos del hombre interior, en espacios abiertos, según quiso la voluntad de Dios.

Retornando a las imágenes, contrasta el modo en que fue representada una coetántea suya, Elisabeth von Schönau, con la que Hildegard mantuvo correspondencia: echada en tierra al pie de la montaña Elisabeth tiene la visión en un estado de raptus, de excessus mentis, in extasim, según las diferentes expresiones por ella misma empleadas (Fig. 4) ${ }^{11}$.

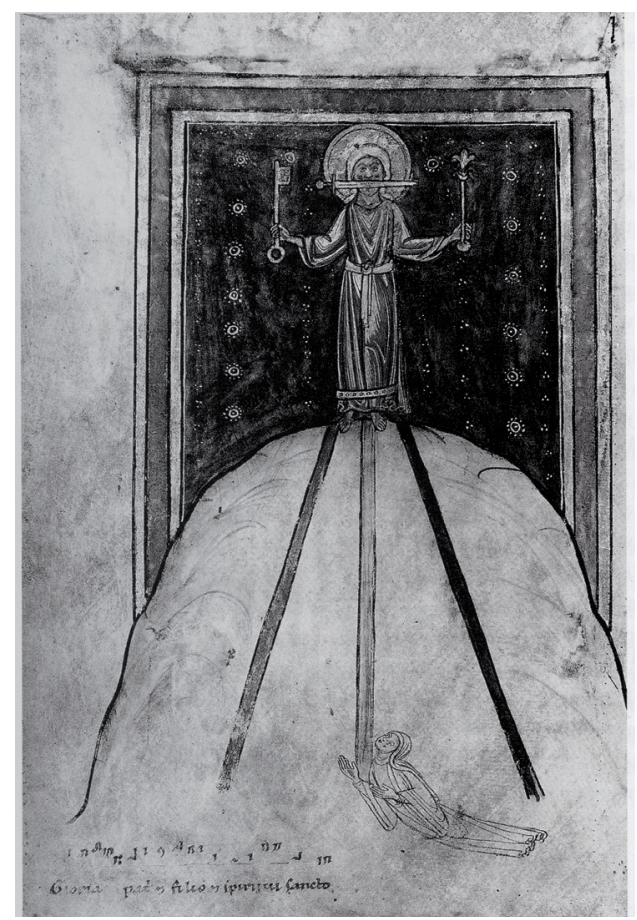

Fig. 4. Elisabeth von Schönau, Visiones, Wiesbaden, Hessische Landesbibliothek, ms. 3, f. $83 \mathrm{v}$.

11 Acerca de su correspondencia con Hildegard con respecto a sus éxtasis, véase V. Cirlot (ed.), Vida y visiones, pp. 121-127. 
Como también resulta contrastante con las imágenes de la Hildegard visionaria, las de Juan de Patmos que, desde los Beatos hasta el ciclo inglés apocalítpico del siglo XIII, aparece en la isla de Patmos dormido, recibiendo la visión del ángel ${ }^{12}$. En la miniatura del Beato se muestra cómo es el espíritu de Juan el que visita las regiones celestes, estableciéndose una relación, incluso podría decirse una identificación, entre visión y sueño (Fig. 5).

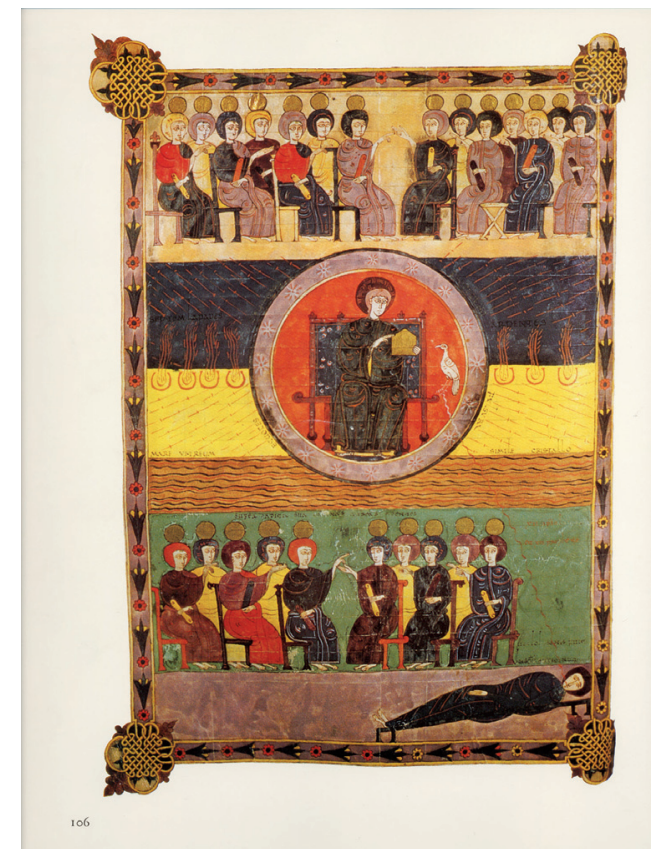

Fig. 5. Beatus Facundus, Madrid, Biblioteca Nacional, Vit 14-2, f. 112v, año 1047.

Los ojos cerrados de Juan parecen oponerse a los ojos abiertos de Hildegard, hasta tal punto que Jean Claude Schmitt interpretó las imágenes de la Hildegard visionaria como un contramodelo del sueño (Gegenbild zum Traum), posiblemente por la sospecha que podían generar las imágenes oníricas, sobre todo tratándose de una mujer ${ }^{13}$. En un estudio sobre el sueño en los textos místicos alemanes del siglo XIV, Alois Maria Haas advertía acerca de la postura crítica que la Edad Media mantuvo siempre con respecto al sueño,

${ }^{12}$ S. Lewis, Reading images, fig. 25, p. 60.

13 J.C. Schmitt, Hildegard von Bingen, pp. 360-364. 
clasificado siguiendo diversas tipologías: la de Macrobio procedente a su vez de Artemiodoro de Daldis, la de Posidonio pasando por Cicerón y Tertuliano hasta la Edad Media o la de Gregorio Magno ${ }^{14}$. En realidad, estas actitudes críticas no distaban mucho de las adoptadas con respecto a la visión, debido sobre todo a la dificultad de determinar sus procedencias. En cualquier caso, Juan de Patmos fue para Hildegard la referencia precisa e inequívoca con la que confrontarse y autocomprenderse. En un pasaje de la Vita, Hildegard relata en primera persona la visión que le impulsó a la escritura del Liber divinorum Operum. Se trata de un pasaje difícil que ha dado lugar a diversas interpretaciones porque Hildegard parece contradecirse con sus anteriores afirmaciones según las cuales nunca había experimentado el éxtasis; pero frente a esta consideración parece más plausible pensar que la visionaria hace referencia a una visio intellectualis en la clasificación agustiniana, aunque con imágenes, pero una visión en la que se habría vaciado absolutamente de sí misma. Lo que ahora interesa sobre todo de este pasaje es la alusión a Juan de Patmos ${ }^{15}$ :

Un tiempo después vi una visión maravillosa y misteriosa, de tal modo que todas mis vísceras fueron sacudidas y apagada la sensualidad de mi cuerpo. Mi conocimiento cambió de tal modo que casi me desconocía a mí misma. Se desparramaron como gotas de suave lluvia de la inspiración de Dios en la conciencia de mi alma, como el Espíritu Santo empapó a san Juan evangelista cuando chupó del pecho de Cristo la profundísima revelación, por lo que su sentido fue tocado por la santa divinidad y se le revelaron los misterios ocultos y las obras, al decir: "En el principio era el verbo, etcétera"

Este Juan al que alude Hildegard es claramente el autor del cuarto evangelio, pero también el autor del Apocalipsis, según la identificación habitual en la Edad Media de ambos autores. Y ahora nos interesa especialmente el Juan del Apocalipsis pues ése es el Juan visionario y, de modo particular, el que vió descender desde lo alto de una montaña a la Jerusalén celeste ${ }^{16}$. La visión de la ciudad celeste que seguidamente pasaré a describir creo que puede entenderse como una actualización del suceso apocalíptico, tal y como permite comprender la teología cristiana según la cual la revelación no es algo irrepetible en el tiempo histórico, sino susceptible de acontecer una y otra vez. En Las grandes corrientes de la mística judía, Gershom G. Scholem lo expuso asi ${ }^{17}$ :

${ }^{14}$ A.M. Haas, Sueño y visión, pp.13-15.

15 V. Cirlot (ed.), Vida y visiones, p. 66.

${ }^{16}$ S. Lewis, Reading images, fig. 163, p. 191.

17 G. Scholem, Las grandes corrientes, p. 29. 
La Revelación, por ejemplo, no es para el místico tan sólo un hecho histórico concreto que, en un momento dado de la historia, pone fin a cualquier otra revelación directa entre Dios y los hombres. Aunque no reniegue de la Revelación como hecho histórico, el místico considera que, para concebir la verdad religiosa, es igualmente importante la fuente de conocimiento y de experiencia religiosa que brota de su propio corazón. Dicho de otro modo, en lugar de un solo acto de Revelación, hay una repetición constante de ese acto. El místico trata de relacionar esta nueva Revelación, que le fue dado vivir a él o a su maestro espiritual, con los textos sagrados del pasado; a ello se debe la nueve interpretación de los textos canónicos y de los libros sagrados de las grandes religiones.

\section{LA VISIÓN DE LA CIUDAD CELESTE}

La visión de la ciudad celeste ocupa la tercera parte de Scivias. Primero aparece un plano general de la ciudad, en la segunda visión, y en las visiones sucesivas se detiene en cada uno de los elementos que forman la ciudad: las torres, los muros y las columnas, (Fig. 6).

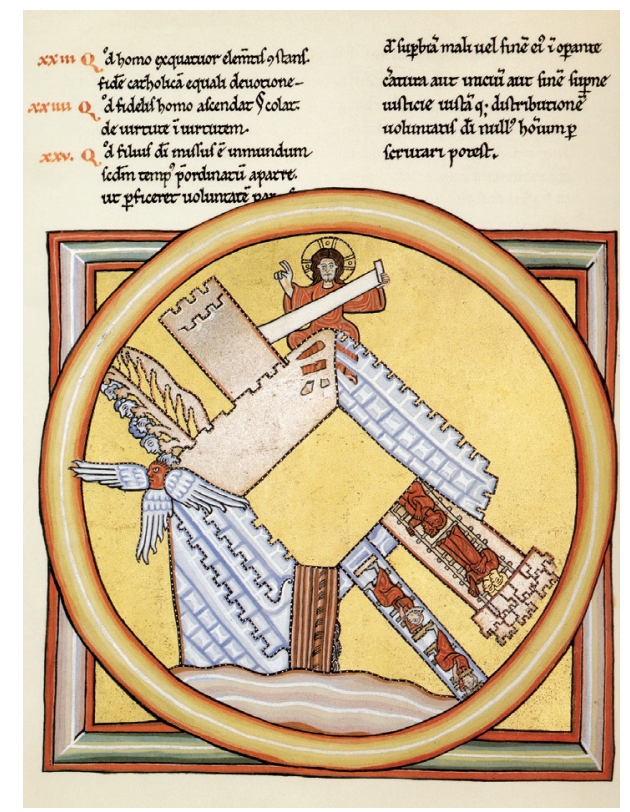

Fig. 6. Hildegard von Bingen, Scivias, facsímil de Eibingen, f. 130v. 
Comencemos por la descripción general de la ciudad acompañada de la miniatura del manuscrito de Wiesbaden ${ }^{18}$ :

Entonces vi, dentro del ámbito del círculo que irradiaba Aquel sentado en el trono, un gran monte, unido a la raíz de la inmensa piedra sobre la que estaban la nube con el trono del sedente, de forma que la piedra se elevaba hacia lo alto y el monte se extendía en las anchuras. Sobre este monte se alzaba un edificio cuadrangular (aedificium quadrangulum), a semejanza de una ciudadela (ad similitudinem urbis quadrangulae) de cuatro esquinas, situado en posición diagonal, de modo que sus ángulos miraban uno al Oriente, otro al Occidente, otro al Aquilón y otro al Mediodía. Alrededor del edificio había una muralla formada por dos elementos: un resplandor brillante como la luz del día (quasi splendor lucidus ut lux diei) y una trabazón de piedras (quasi compaginatio lapidum), que convergían ambos en el ángulo oriental y en el septentrional; así que la parte luminosa de la muralla se prolongaba, intacta y sin interrupción, desde el ángulo oriental hasta el septentrional; y la parte pétrea se extendía desde el ángulo septentrional, por el occidental y el meridional, hasta terminar en el oriental, con dos espacios huecos: entre el ángulo occidental y el meridional. La longitud del edificio era de cien codos, su anchura de cincuenta y su altura de cinco, de modo que los muros laterales tenían el mismo largo, como también los muros frontal y posterior. Los cuatro muros alcanzaban igual altura en todo su recorrido, excepto en los torreones, que la rebasaban ligeramente. La distancia entre el edificio y el fulgor del círculo mencionado, que se extendía hasta las profundidades del abismo, era de un palmo en el vértice oriental; pero en los demás -septentrional, occidental y meridiano- era de tal magnitud que no pude calcularla.

En esta miniatura, como en otras de este mismo manuscrito o en las del manuscrito de Lucca, es posible apreciar el carácter diagramático con que se resuelven las visiones de Hildegard. Las figuras geométricas, en este caso el círculo y el cuadrado interior que es la ciudad propiamente dicha, además del cuadrado exterior que funciona como marco de toda la composición, destacan con gran nitidez en la representación ${ }^{19}$. Tal y como ocurre en toda visión, Hildegard ve formas que no pueden ser totalmente identificadas con las formas terrenales, sino que simplemente se parecen (ad similitudinem). Se trata de una urbs quadrata, pero en una posición oblicua de modo que adopta una forma romboidal. En la descripción se observa la necesidad de determinar los puntos cardinales que siguen la orientación de la geografía visionaria según la

${ }^{18}$ H. de Bingen, Scivias: Conoce los caminos, p. 283.

${ }_{19}$ M. Evans, The geometry. 
cual el Norte es el Oriente ${ }^{20}$. Junto a las medidas, se alude a los materiales del muro: la luz resplandeciente y las piedras. La luz envuelve todas las visiones de Hildegard que en una carta a Guibert de Gembloux del año 1175, célebre por ser considerada su manifiesto visionario, le confesaba la coexistencia de dos luces en su interior: una de ellas le acompañaba siempre, y la otra era poderosísima y sólo la veía de vez en cuando (luz viviente) ${ }^{21}$. Resplandor, fulgor, centellas, chispas, efectos que el miniaturista pretende crear con el oro y el púrpura, junto con las texturas líquidas, especulares y umbrosas, nos sitúan de lleno en el mundo visionario ${ }^{22}$. El muro de luz es el elemento celeste de la ciudad cuyo vértice superior, en el ángulo oriental, se encuentra presidido por un Cristo majestad. Comparemos esta imagen de ciudad con uno de los primeros mapas existentes de Jerusalén. Me refiero ahora, no a la celestial, sino a la terrestre. Se trata del mapa de Cambrai fechado entre 1140-1150 (Fig. 7), es decir, en los mismos años en que Hildegard escribía Scivias.

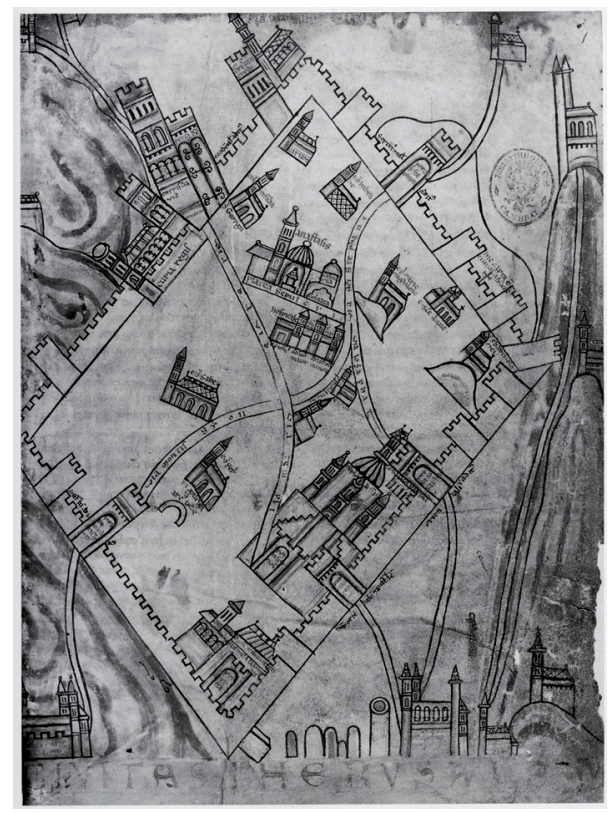

Fig. 7. Mapa de Jerusalén, Cambrai, Biblioteca Municipal, ms. 466, f. 1r, tercer cuarto del siglo XII.

${ }^{20}$ Véase sobre esta cuestión, M. Cristiani, M. Pereira (eds.), Il libro delle opere, p. 1150.

${ }^{21}$ V. Cirlot (ed.), Vida y visiones, pp. 135-154.

${ }^{22}$ V. Cirlot, Hildegard von Bingen y la tradición, pp. 162-170. 
Según Heydenreich el mapa se caracteriza por un intenso realismo, hasta tal punto que la forma romboidal que adopta a diferencia de la circular habitual (Fig. 8), parece reproducir la situación de la Jerusalén real; además hay indicaciones precisas, como por ejemplo, una que señala por dónde fue tomada la ciudad por los cruzados franceses (hic capta est civitas a francis) que coincide con toda exactitud con las fuentes históricas que narran el asalto a la ciudad el 15 de julio de 1099 o, por ejemplo, la que identifica la torre de Tancredo refiriéndose al príncipe Tancredo de Hauteville citado en De situ urbis Jherusalem (entre 1130-50). El hecho de que nombre monumentos que no constan en ningún otro lugar, ni textuales ni en mapas, como las iglesias de san Bartolomeus y S. Habraha (ambas en el noreste) o san Salvator (entre la via Josafat y la del Monte Sión), parece apuntar a que el mapa fue realizado por alguien que conoció bien la ciudad, probablemente un cruzado del círculo de los condes de Alsacia, en concreto de Thierry de Alsacia que visitó en tres ocasiones Tierra santa (1138, 1147 y 1163); el códice está relacionado de algún modo con la familia ya que contiene cartas de Federico Barbarroja a Thierry y a Felipe de Alsacia (f. 93) ${ }^{23}$. La comparación de la miniatura de la ciudad vista por Hildegard y el folio 1 del mapa de Cambrai, prácticamente coetáneos, muestra las semejanzas entre ambas imágenes apuntando a la idea de la correspondencia entre ambas Jerusalenes en el imaginario de la época, pero también las distingue con claridad: la ciudad de Hildegard está presidida por Cristo Majestad, presencia que resulta transfiguradora y la convierte en la Ciudad de Dios, al tiempo que hace flagrante su ausencia en la Jerusalén del mapa.

En esta tercera parte del Scivias a la descripción del plano general de la ciudad sigue la exégesis de los significados: la montaña representa la fe, y si está colocada en la raíz de la inmensa piedra que alberga el misterio del temor de Dios se debe a que la fe está unida a la perseverancia en el temor de Dios y el temor de Dios, a la fortaleza de la $\mathrm{fe}^{24}$.Cuando se determina el significado del edificio cuadrangular semejante a la ciudad cuadrangular se dice que ${ }^{25}$ :

La bondad del Padre edifica buenas obras sobre la fe, reúne muchos fieles de los cuatro ángulos de la tierra y los atrae hacia lo celestial para que, afianzados en la firmeza de la virtud, el Padre Supremo los coloque benignamente en Su seno, en Su secreta potestad y místico designio, con los cuatro fundamentos de la fe.

${ }^{23}$ L.H. Heydenreich, Ein Jerusalem-Plan.

${ }^{24}$ H. de Bingen, Scivias: conoce los caminos, p. 284.

${ }^{25}$ Ibidem, p. 285. 


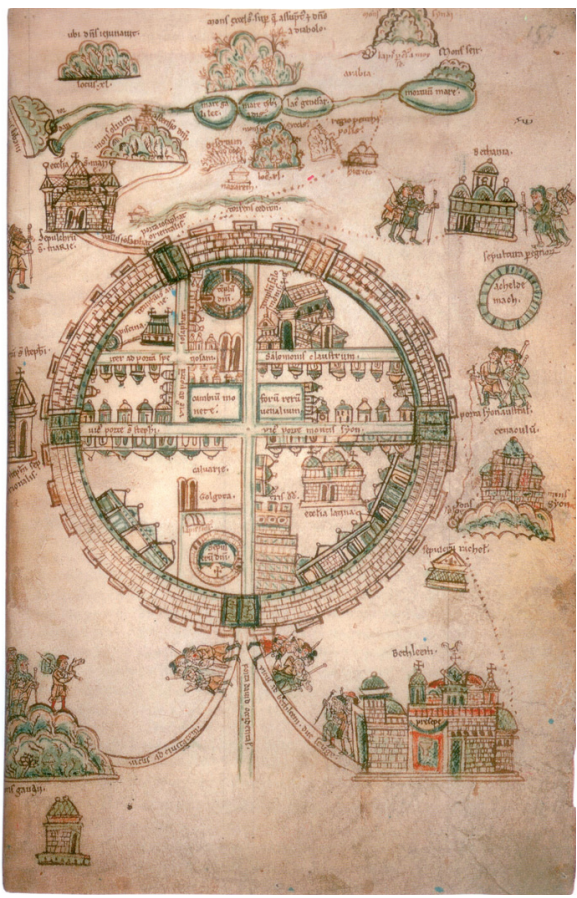

Fig. 8. Mapa de Jerusalén, Bruselas, Royal Library de Bélgica, ms. 9823-9824, f. $157 \mathrm{r}$, segunda mitad del siglo XII.

Más adelante la voz celeste sostiene ${ }^{26}$ :

Yo, el Altísimo, formé para Mi obra el primer fundamento de los hombres, Adán, cuya estirpe, desaparecido él, perduró, debilitándose por un gran cisma, hasta el segundo fundamento, hasta Noé; entonces se desencadenó el diluvio, y allí anuncié los misterios de Mi Hijo en el arca.

La tercera piedra son Abraham y Moisés unidos por la circuncisión y en la Ley, y la cuarta piedra es la santa Trinidad. El hecho de que el edificio se encuentre en una posición ligeramente oblicua se debe a que ${ }^{27}$ :

${ }^{26}$ Ibidem, p. 285.

${ }^{27}$ Ibidem, p. 286. 
El hombre, que es obra de Dios, no puede, por su fragilidad, caminar firmemente sin pecado y, con audacia, sin temer por su desvalida carne, vencer al Demonio; sino que debe evitarlo con humildad y rehuir con sabiduría sus celadas para no pecar. Que se una fielmente al bien y se edifique, así, en el Hijo de Dios que, sentado en un ángulo, es la piedra angular, en Quien se eleva la trabazón de los fieles en la obra santa.

Así, cada uno de los aspectos del edificio posee un significado interior (temor de Dios, fe, bondad, etc.); además, el edificio se presenta como una espacialización de la historia sagrada: el tiempo de Adán, de Noé, de Abraham y Moisés Los diferentes materiales del muro se explican en relación con la ciencia especulativa, esto es, el discernimiento del bien y del mal, según su aparición y despliegue en la historia ${ }^{28}$.

La parte luminosa de la muralla se prolongaba, intacta y sin interrupción, desde el ángulo oriental hasta el septentrional: la ciencia especulativa, que afianza los corazones humanos, amaneció en el ángulo oriental, en los días de Noé; porque antes de Noé la iniquidad porfiaba por conseguir hacer cuanto pudiera para escarnio del Señor.

Se establece con suma precisión las correspondencias entre los aspectos físicos y las verdades interiores, las asociaciones entre planos de realidades diferentes, un despliegue que manifiesta una concepción del mundo simbólica. A veces resultan excesivamente prolijas para nuestra mentalidad, incomprensibles, y se tiene la sensación -yo diría que es una sensación que procede de haber leído a Lévi-Strauss-, de que lo único que importa es la estructura, el orden. Presentaré el despliegue del edificio cuadrangular del modo más sintético posible, pero es necesario hacerlo para tener una idea de la visión de Hildegard. Así, una vez se ha descrito la forma general del edificio o ciudad cuadrangular, se procede a la visión particular de cada uno de los elementos que lo conforman.

El primero es: la torre de color de hierro (Fig. 9), en la que distingue cinco figuras, cada una de ellas mirando a una dirección, de modo que vuelve a tener lugar una orientación concreta del elemento arquitectónico ${ }^{29}$ :

${ }^{28}$ Ibidem, p. 291.

${ }^{29}$ Ibidem, p. 301. 


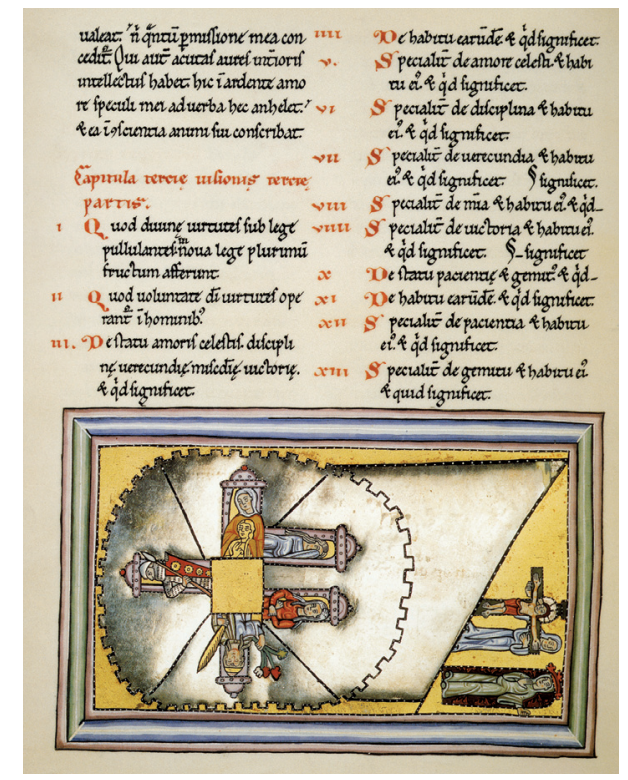

Fig. 9. Hildegard von Bingen, Scivias, facsímil de Eibingen, f. 138v.

La primera miraba hacia el Oriente, la segunda al Aquilón, la tercera al Septentrión, la cuarta a la Columna de la Palabra de Dios, en cuya base estaba el patriarca Abraham, y la quinta a la torre de la Iglesia y a los hombres que, dentro del edificio, iban de un lado a otro.

La primera imagen es el amor celestial, la segunda, la disciplina, la tercera, el pudor, la cuarta, la misericordia, la quinta anuncia la victoria. La cuarta visión la ocupa la columna de la palabra de Dios (Fig. 10) colocada en el exterior de la parte luminosa del muro. A la visionaria le parece terrible y sus dimensiones gigantescas le impiden medirla.

Del ángulo dirigido a oriente salían ramas desde la raíz hasta la cima: Abraham sentado en la primera rama, Moisés en la segunda, Josué en la tercera y así todos los patriarcas y profetas, y todos estaban girados hacia el ángulo septentrional admirando las cosas futuras. En la cima de la columna en medio de una gran claridad había una paloma con un rayo dorado en el pico. En el interior del edificio se distingue una imagen de la que emana una gran claridad 


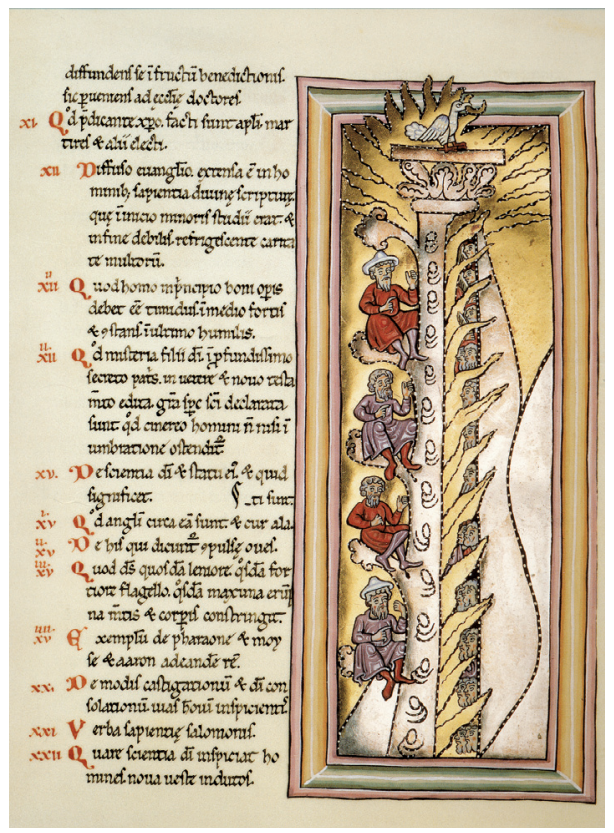

Fig. 10. Hildegard von Bingen, Scivias, facsímil de Eibingen, f. 145v.

y que es identificada en la exégesis con la ciencia de Dios ${ }^{30}$. La quinta visión corresponde a la ira de Dios (Fig. 11) ${ }^{31}$ :

Después de esto miré y he aquí que, en el ángulo septentrional, donde convergen las dos partes de la muralla del edificio mencionado, había una cabeza de prodigiosa forma; estaba sujete, inamoviblemente, por el cuello, al exterior de ese ángulo, y a igual distancia que este de la tierra, sin sobrepasarlo, sino que coincidían en la cima, en el mismo plano de altura. Esta cabeza era del color del fuego, rutilante cual ígnea llama, y tenía un terrible rostro humano que, lleno de ira, miraba hacia el Aquilón.

En el capítulo 21 de esta vision da entrada a una historia bíblica de la construcción del templo. Se trata de la historia de Jacob ${ }^{32}$ :

${ }^{30}$ Ibidem, pp. 315-328.

${ }^{31}$ Ibidem, p. 329.

32 Ibidem, p. 340. 
Levantose Jacob de madrugada, y tomando la piedra que se había puesto por cabezal, la erigió como estela y derramó aceite sobre ella. Y llamó a aquel lugar Betel (...) y la erigió como estela del Libro de la Vida, como efigie del sublime Aroma de la Jerusalén celestial; pues igual que Cristo es la Cabeza de Sus miembros en la Jerusalén eterna, todo altar consagrado es la parte más excelsa de Su templo, rociado con el óleo, señal del crisma: la efusión de la gracia de Dios Omnipotente en el santo bautismo. Y llamó a este lugar santificado Morada y Templo de Dios, según el nombre de la ciudad celestial Jerusalén: Templo vivo del Dios Vivo.

El breve relato alude a la construcción del templo que se realiza con una piedra pero "dándole la forma de libro" y "el olor poderoso de la Jerusalén celeste". Atendamos a las mutaciones del objeto: piedra/libro de vida/olor, y todo ello encuentra un paralelismo según el cual el cuerpo de Cristo es la misma construcción celeste. Las metamorfosis objetuales indican la necesidad del mundo de las formas para la visualización, pero también ese carácter mutante incide en el valor de los significados invisibles que es el verdadero objetivo simbólico.

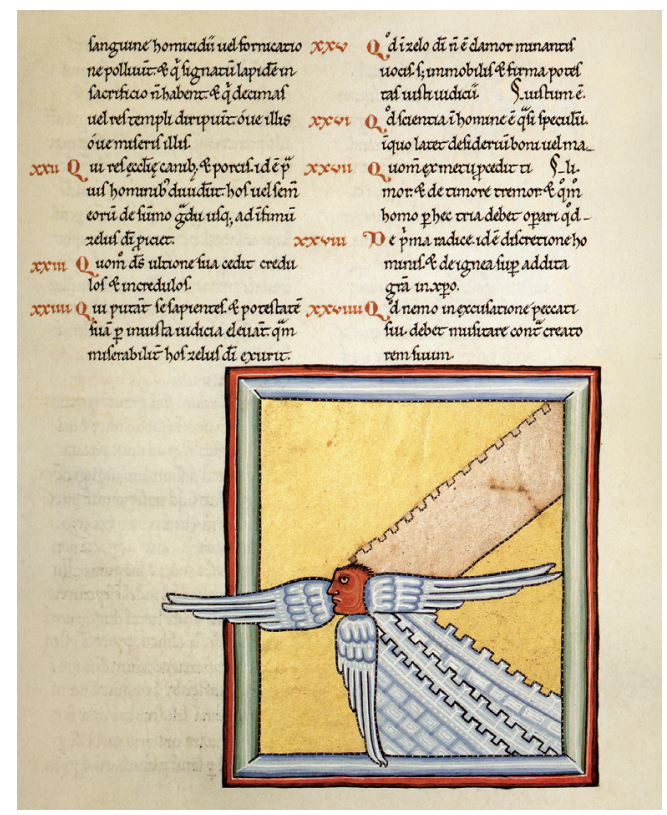

Fig. 11. Hildegard von Bingen, Scivias, facsímil de Eibingen, f. 153r. 
Este microrelato resulta central en esta visión de la ciudad celeste de la tercera parte del Scivias, pues creo que puede entenderse como espejo de toda la obra construida y en construcción que va desgranando visión tras visión. En la sexta visión, el muro de la alianza (Fig. 12), el elemento arquitectónico también está poblado de figuras ${ }^{33}$ :

Después vi el muro emplazado entre el ángulo septentrional y el occidental del mencionado edificio; su parte interna la formaba una arquería, igual que una cancela, pero de arcos ciegos, y en cada uno de ellos figuraba como el retrato de un hombre.

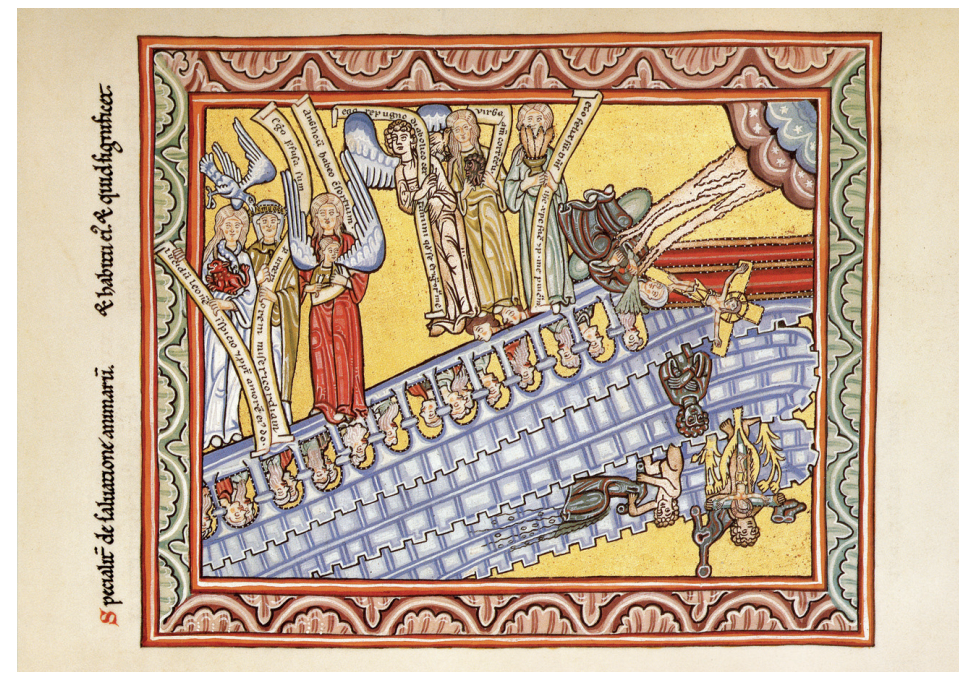

Fig. 12. Hildegard von Bingen, Scivias, facsímil de Eibingen, f. 161v.

Una serie de imágenes, cuyos vestidos y colores son descritos con toda precisión, son comparadas unas con otras estableciéndose los elementos comunes y los dispares, todas ellas con atributos propios y con significados que se desprenden de las palabras que profieren. La miniatura no puede dar cuenta de la extrema animación de la visión que sólo el cine podría representar. La séptima visión (Fig. 13) está dedicada a la columna de la Trinidad ${ }^{34}$ :

${ }^{33}$ Ibidem, p. 347.

${ }^{34}$ Ibidem, p. 371. 
Luego vi, en el ángulo occidental del mencionado edificio, una columna admirable, misteriosa y muy recia, de un color púrpura negruzco, emplazada de tal modo en el ángulo, que era visible desde dentro y fuera del edificio. Tan inmensa era, que su grosor y altura desbordaban mi entendimiento, sólo pude advertir su prodigiosa tersura, sin rugosidad alguna.

La columna tiene tres aristas que aluden a la Trinidad. En la obra hildegardiana la iconografía trinitaria se resuelve con imágenes tradicionales, siguiendo, por ejemplo, el tipo Gnadenstuhl, Dios Padre acogiendo en su regazo al cordero con la paloma sobre su cabeza ${ }^{35}$, pero también ofrece imágenes insólitas como ésta, pues si bien la columna simboliza a Cristo, en cambio, no se encuentran ejemplos en la tradición iconográfica en que aparezca como símbolo trinitario ${ }^{36}$. El miniaturista ha creado, siguiendo fielmente el texto, una imagen nueva como sucede en muchas otras ocasiones en la obra de la visionaria. Importantes son las palabras que pronuncia la voz del cielo ${ }^{37}$ :

Oh hombre, esta plenitud de dones místicos, prodigiosos y desconocidos que ves diáfanamente en la luz verdadera, Yo te los revelo y te digo: mira, ve y anúncialos, enséñalos y que se enciendan los corazones de fuego de los fieles, que son las piedras más puras para edificar la Jerusalén Celestial.

De nuevo se cita a la Jerusalén celeste y aquí se introduce la elaboración hildegardiana sobre la ciudad en la que ésta no es tanto la que desciende de los cielos ante la mirada de Juan, la ciudad completa del fin de los tiempos, ubicada en un cielo nuevo y una nueva tierra, sino la ciudad que crece y es construida en el tiempo. Una de las expresiones más habituales en la correspondencia de Hildegard como despedida a su destinatario hace referencia a esta cuestión: regocíjate ahora por la salvación de tu alma y serás una piedra viva en la Jerusalén celeste ${ }^{38}$.

35 Véase Scivias, f. 225v.

${ }^{36}$ F. Boespflug, Y. Zaluska, Le dogme trinitaire.

${ }^{37}$ H. de Bingen, Scivias: conoce los caminos, p. 371.

${ }^{38} \mathrm{H}$. of Bingen, The Letters of Hildegard of Bingen, vol. I, n.148r. 


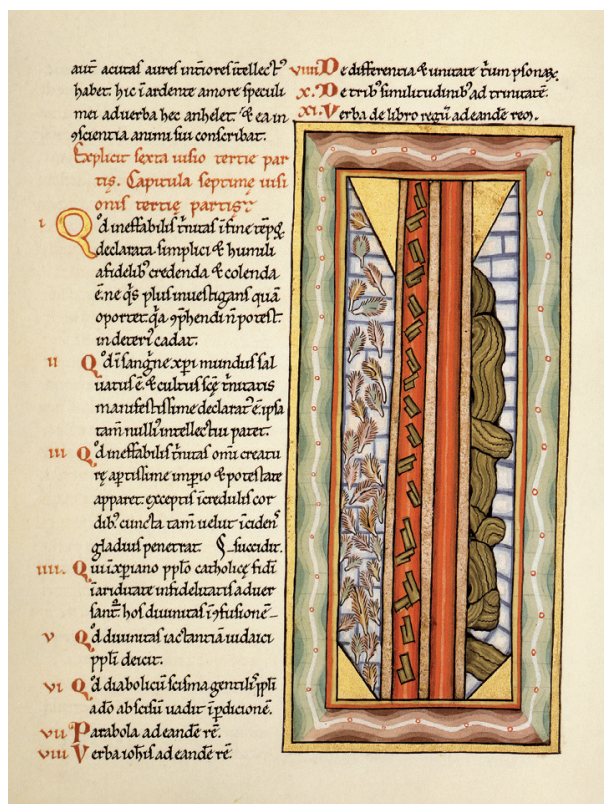

Fig. 13. Hildegard von Bingen, Scivias, facsímil de Eibingen, f. 172r.

La Jerusalen celeste es una ciudad en construcción que se realiza con piedras que son las virtudes, las buenas obras de los fieles. La referencia se encuentra en la primera epístola de san Pedro 2, 4: Acercándoos a él, piedra viva, desechada por los hombres, pero elegida, preciosa ante Dios, también vosotros, cual piedras vivas, entrad en la construcción de un edificio espiritual. La construcción de la ciudad constituye para Hildegard una metáfora eficaz para comprender las verdades interiores que tienen que ver con el comportamiento ético y moral. La visión octava (Fig. 14), nos muestra justamente el acto de construcción ${ }^{39}$ :

Después vi, en la parte sur del muro de piedra del edificio, allende la columna de la Trinidad verdadera, otra columna grande y oscura, visible desde dentro y fuera del edificio, a mis ojos tan umbrosa, que ni su grosor ni su altura pude discernir.

${ }^{39}$ H. de Bingen, Scivias: conoce los caminos, p. 383. 


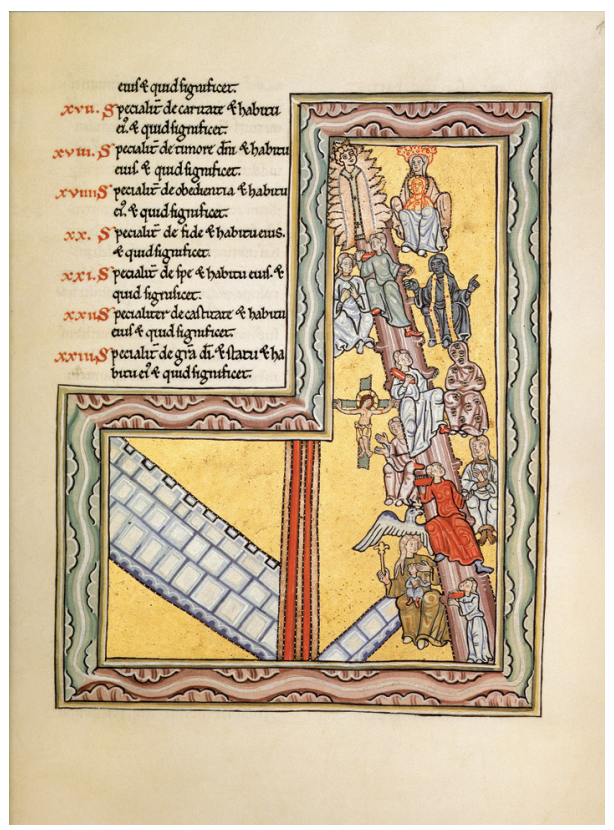

Fig. 14. Hildegard von Bingen, Scivias, facsímil de Eibingen, f. 178r.

Más adelante, acontece la visión de las dos luces ${ }^{40}$ :

Y esta umbría columna se alzaba en el edificio en el mismo lugar sobre el que había visto yo antes, en los arcanos celestiales ante la faz del Señor, aquel inmenso esplendor de cuatro haces y luminosísimo brillo que, simbolizando el misterio del Creador Supremo, se me manifestó en medio del más grande secreto, y en el que rutilaba otro fulgor, semejante a la alborada que alberga en su etérea claridad una intensa luz púrpura, como revelación mística que me ilustró el misterio del Hijo de Dios encarnado.

Se muestra ahora la actividad constructora realizada por las siete virtudes, los dones del espíritu en la exégesis, que ascienden y descienden la escalera con las piedras ${ }^{41}$ :

En esta columna había, de la base a la cima, un camino ascendente a modo de escalinata por donde vi a todas las virtudes de Dios

${ }^{40}$ Ibidem, p. 383.

${ }^{41}$ Ibidem, p. 383. 
bajar y subir, cargando piedras para su obra, con denodado ahínco en cumplirla.

La novena visión es la torre de la iglesia (Fig. 15). La crítica hildegardiana ha reconocido una influencia clara del Pastor Hermas ${ }^{42}$. Destaca por su carácter inacabado ${ }^{43}$ :

Después vi, allende la columna de la Humanidad del Salvador, una torre de radiante esplendor, emplazada de tal modo en el muro de piedra, al sur del edificio, que era visible desde dentro y fuera del mismo; en la parte interior su contorno medía cinco codos de ancho, pero no pude calcular su inmensa altura. Entre esta torre y la columna de la Humanidad del Salvador se veía un hueco, un espacio vacío de un codo de ancho, en el que sólo yacían los fundamentos, aún sin edificar el muro, según se ha referido ya. Pero la torre no estaba todavía rematada.

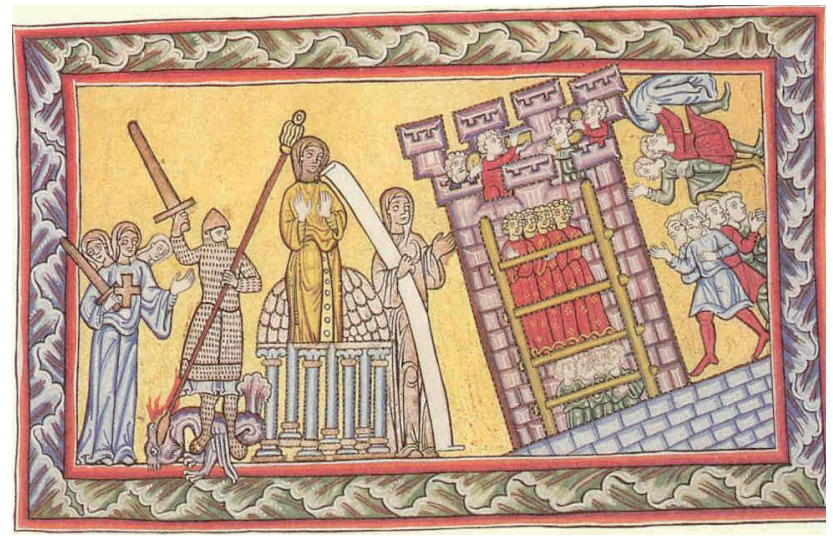

Fig. 15. Hildegard von Bingen, Scivias, facsímil de Eibingen, f. 192r. $(\text { Fig. 16) })^{44}$ :

Finalmente, la décima visión está reservada al Hijo del Hombre

Y después vi, en la cima del ángulo oriental del edificio referido -donde se unían las dos partes, de luz y piedra, de la muralla-, siete gradas de blanquísima piedra que ascendían, a guisa de testudo,

42 P. Dronke, Las escritoras, p. 224.

${ }^{43}$ H. de Bingen, Scivias: conoce los caminos, p. 411.

${ }^{44}$ Ibidem, p. 435 
hasta la gran roca sobre la que estaba el Ser luminoso sentado en el trono.

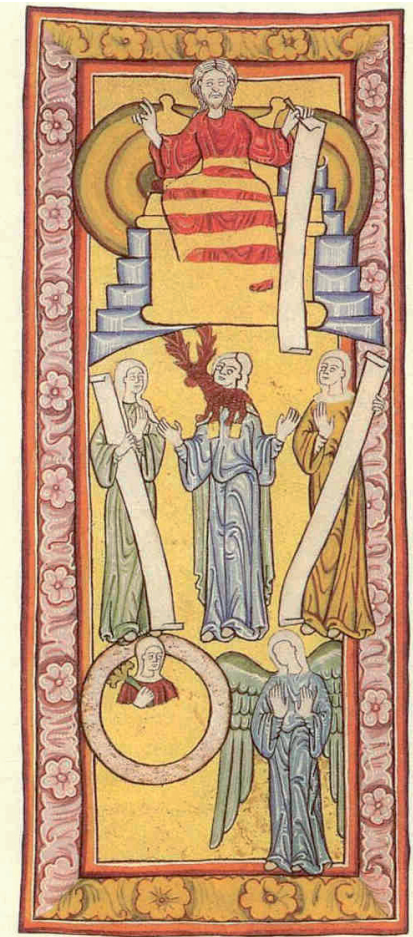

Fig. 16. Hildegard von Bingen, Scivias, facsímil de Eibingen, f. 202v.

Hasta aquí la visión de la ciudad celeste en Scivias, su descripción y algunos aspectos de su exégesis.

En el Liber divinorum operum vuelve a aparecer la ciudad en la tercera parte (Fig. 17). Sin embargo, en este caso Hildegard no la describe y remite a su obra anterior Scivias. Sólo se encuentra una breve alusión en la visión primera ${ }^{45}$ :

Y nuevamente vi como un instrumento cuadrado que parecía una gran ciudad (quasi cuiusdam magne ciuitatis instrumentum quadratum), circundada por todas partes, como con un muro, de gran esplendor y tinieblas, y adornado con montes e imágenes. Vi en el

\footnotetext{
${ }^{45}$ H. de Bingen, Libro de las obras, p. 475; Hildegardis Bingensis Liber Divinorum, p. 345.
} 
medio de la región oriental como un monte grande y alto, hecho de piedra dura y blanca, similar a la piedra que escupe el fuego; sobre este monte resplandecía como un espejo de tan gran claridad y pureza, que parecía sobrepasar el resplandor del sol; sobre éste aparecía como una paloma con alas extendidas, como preparada para volar. Este espejo, que contenía en sí muchos milagros ocultos, emitía un esplendor de gran latitud y altitud, en el que aparecían muchos misterios y formas de diversas imágenes.

En la exégesis el instrumento cuadrado que parecía una gran ciudad significa la estabilidad y la firmeza de la predestinación divina ${ }^{46}$ :

Ves como un instrumento cuadrado que parece una gran ciudad, que significa la obra estable y firme de la predestinación divina; circundado por todas partes, como con un muro, de gran esplendor y tinieblas, porque los fieles son considerados para la gloria, pero los infieles para los castigos, divididos por el justo juicio. $Y$ adornado con montes e imágenes, esto es, fortificado y elevado por los grandes prodigios de los milagros y de las virtudes.

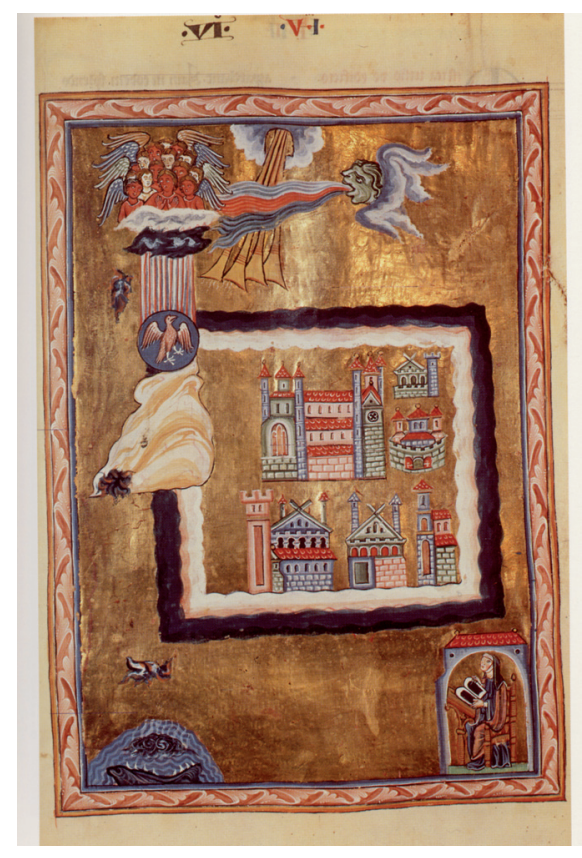

Fig. 17. Hildegard von Bingen, Liber divinorum operum, ms. de Lucca, f. 118r.

\footnotetext{
${ }^{46}$ H. de Bingen, Libro de las obras, p. 476.
} 
En el epílogo encontramos la mención a la Jerusalén celeste ${ }^{47}$ :

Y yo pobrecita, adoctrinada en este misma visión, decía: "Señor mío, dales a todos los que me ayudaron, consolándome a mí, que he trabajado con gran temor en estas visiones que grabaste en mí desde mi infancia, la recompensa de la claridad eterna en la Jerusalén Celestial, de manera que se alegren infinitamente en Ti."

A pesar de que la ciudad celeste aparezca en el Liber sólo de esta forma implícita, no hay duda de que es el auténtico tema de esta parte tercera, como bien comprendió el ilustrador del manuscrito de Lucca que introdujo el cuadrado en todas las miniaturas que la ilustraron. El carácter diagramático del Liber divinorum operum resulta todavía más acusado que en Scivias, pues aquí se trata de una sucesión de círculos y cuadrados. El círculo domina las visiones segunda, tercera y cuarta para dar paso al cuadrado en las siguientes y reunir a ambas en la última visión. En lo que respecta particularmente al asunto que aquí nos interesa, la ciudad celeste, Hildegard proyecta mediante el uso de motivos escatológicos las últimas etapas de la construcción de la ciudad humana-divina y ve esas etapas llenas de ascensos y descensos, unas veces avanzando y otras retrocediendo, pero su última convicción es optimista: la ciudad será realizada. Detengámonos un momento en esta décima y última visión del Liber (Fig. 18).

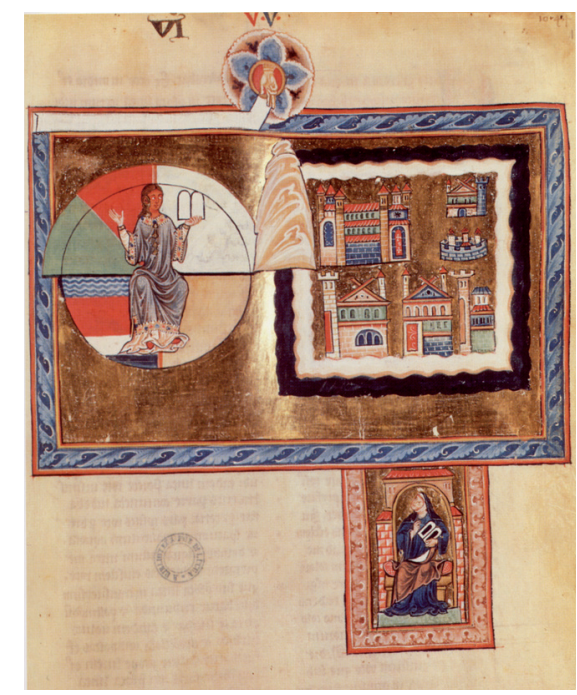

Fig. 18. Hildegard von Bingen, Liber divinorum operum, ms. de Lucca, f. 143r.

\footnotetext{
${ }^{47}$ Ibidem, p. 614.
} 
La rueda cósmica está dominada por la figura verde de la CaritasSapientia, que llena toda la parte izquierda, mientras que la otra mitad de la derecha está ocupada por el cuadrado, símbolo de la ciudad. La montaña sirve de unión entre la rueda y el cuadrado. Si el círculo simboliza la divinidad, el cuadrado alude a la tierra, pero el color dorado le otorga un carácter sagrado. Como sostuvo Ingrid Riedel, al círculo de la teofanía de Sofía corresponde la cuadratura de la ciudad ${ }^{48}$. La ciudad es en efecto la obra que los hombres deben construir, pero no es una obra terrenal, sino que tal como hemos podido ver a través de las descripciones, es una obra de luz, es decir, celeste. En Scivias pude detectar un pasaje en la cuarta visión de la Primera parte titulada "El hombre en su tabernáculo" a la cual podría aplicarse la expresión acuñada por Henry Corbin de "dramaturgia del alma" (Fig. 19)"

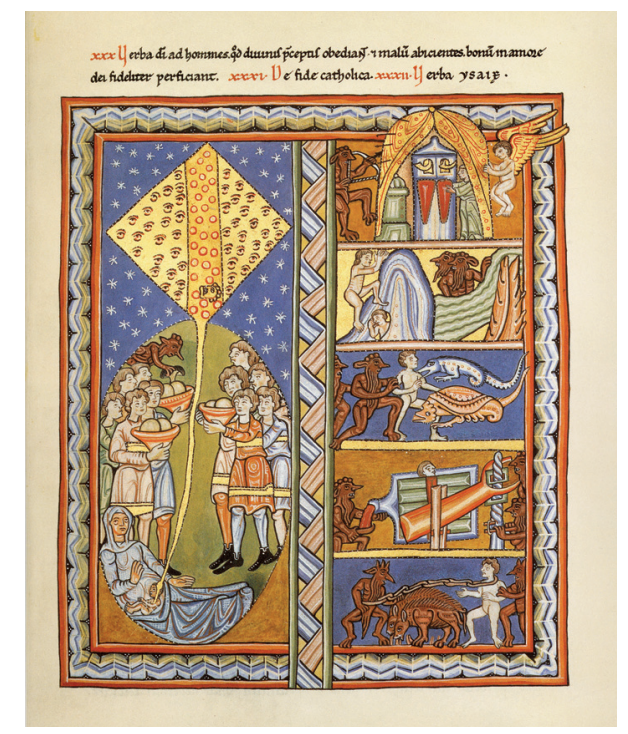

Fig. 19. Hildegard von Bingen, Scivias, facsímil de Eibingen, f. 22r.

Constituye un relato "del exilio de Occidente". Se trata de uno de los escasos pasajes en que la Voz del Ser se encuentra sustituida por la voz del alma que se lamenta contando una historia que la miniatura reprodujo en la parte derecha y según un esquema de composición narrativo en cinco registros

48 I. Riedel, Hildegards Sophia-Vision, p. 412.

49 Así lo planteé en V. Cirlot, Hildegard von Bingen y la tradición, pp. 159-182. 
que se van sucediendo en una línea ascendente de abajo a arriba, contraria a la parte izquierda de la miniatura en la que el esplendor de luz y su halo marcaban un ritmo descendente. La historia relatada por el alma se prolonga a lo largo de ocho capítulos en los que tiene lugar el movimiento ascendente en búsqueda de la luz que la opacidad del cuerpo impide ver. Es el retorno al hogar del alma exiliada de un mundo que le es extraño. Después de las primeras aventuras que ocupan los cuatro primeros registros y que consisten en el modo en que el alma supera obstáculos insalvables, alcanzamos el quinto registro donde el alma aparece como ángel con alas junto al tabernáculo que el artista resolvió con el oro y rojo. El alma alcanza el tabernáculo donde realizará "las obras de luz cuando antes las había hecho de tinieblas" (opera claritatis feci, cum prius opera tenebrarum fecissem). La liberación de la luz se concibe como la construcción del templo. A cada punto cardinal del tabernáculo corresponde un elemento arquitectónico y un ritual litúrgico ${ }^{50}$ :

En la zona norte del tabernáculo instalé una columna de hierro sin pulimentar, de la que colgué abanicos de distintas plumas, que se mecían aquí y allá. Encontré maná y comí. En la zona oriental edifiqué una muralla con piedras cuadradas. Y encendiendo allí un fuego, bebí un vino perfumado con mirra, y mosto. En la parte que mira al mediodía levanté una torre de piedras cuadradas de la que colgué escudos de color bermejo, y en sus ventanas coloqué trompetas de marfil. En el centro de esa torre derramé miel y preparé con ella y con hierbas aromáticas un bálsamo maravilloso, cuyo magnífico olor se extendió por todo el tabernáculo. Mas en la zona de occidente no hice obra alguna, pues estaba orientada hacia el mundo.

La pasión de Hildegard por la imagen de la Jerusalén celeste se manifiesta también en su obra poética y musical, Symphonia, en la que afloran elementos característicos de la descripción de la ciudad en Apocalipsis 20. Pero también en este caso, al igual que en su obra profética, la Jerusalén de Hildegard es una ciudad por construir. Indica Barbara Newman que tres son los elementos constantes en Symphonia: árbol, edificio, montaña, emblemas que aparecen en múltiples permutaciones. El árbol y el edificio son metonimias para las dos imágenes de suprema realización: el jardín al principio de los tiempos,y la ciudad, al final. Expulsada del jardín, la raza humana hace su peregrinación lenta y tortuosa hacia la Ciudad por el camino de la montaña. La construcción de la ciudad es un esfuerzo compartido, imagen de la constante interacción de la gracia divina y el combate humano ${ }^{51}$. En $O$ presul vere civi-

${ }^{50}$ H. de Bingen, Scivias: conoce los caminos, p. 67.

${ }^{51}$ B. Newman (ed.), Symphonia, p. 50. 
tatis dedicada a san Disibodo se da entrada a la paradoja arquitectónica, muy empleada por Hildegard, según la cual la construcción es al mismo tiempo el constructor. En la estrofa $4^{\mathrm{a}}$ se dice: ${ }^{\mathrm{a}}$ Tu magna turris/ante altare summi Dei, et huius turris culmen obumbrasti/per fumum aromatum/ (Tú, gran torre/ante el altar del sumo Dios,/también has oscurecido la cima de esta torre/con el humo de las especias) $)^{52}$. Disibodo es el sacerdote que ofrenda el humo de las especias ante el altar divino de modo que oscurece la cima de la torre y es la torre misma. Oh Jerusalem parece que fue compuesta para la consagración de la nueva iglesia monástica de Rupertsberg consagrada el 1 de mayo de 1152, la pieza más larga y más elaborada de Symphonia. Las estrofas 7 y 8 son un eco del Himno Urbs beata Hierusalem. La secuencia de Hildegard conmemora no sólo a Rupert sino a la comunidad de los santos, las piedras vivas de la Jerusalén celestial. Aunque no haya citas literales la descripción de Jerusalén contiene claras resonancias apocalípticas: O Ierusalem, aurea civitas/ornata regis purpura/... Fenestre tue, Ierusalem,/cum topacio et saphiro/specialiter sunt decorate ( $¡ J e r u s a l e ́ n$, ciudad de oro,/adornada de púrpura real!/.../Tus ventanas, Jerusalén,/con topacio y zafiro/han sido totalmente decoradas) ${ }^{53}$. Y de nuevo la Jerusalén celeste como cuerpo vivo destaca en versos como éste: O Ierusalem,/fundamentum tuum positum est/cum torrentibus lapidibus, I quod est cum publicanis et peccatoribus/qui perdite oves erant,/sed pero Filium Dei invente,/ad te cucurrerunt/et in te positi sunt. (¡Jerusalén!,/tu cimiento se ha asentado/con piedras ardientes,/publicanos/ y pecadores,/ que eran ovejas perdidas./Pero, encontradas por el Hijo de Dios,/corrieron hacia ti/y te han sido ofrecidas) ${ }^{54}$.

Finalizaré esta descripción de la ciudad celeste en la obra de Hildegard con una carta escrita a un destinatario desconocido, fechada entre 1173-1179, esto es, en los últimos años de su vida, que es justamente un comentario a la visión de Juan de Patmos de la Jerusalén celeste. El primer párrafo de la carta concluye: fue Juan quien dijo en una visión mística: " $Y$ vi la ciudad santa", etc ${ }^{55}$. La cita de Apocalipsis 21,2 adquiere especial resonancia después de la lectura de la tercera parte de Scivias. La relación especular que Hildegard establece con Juan se hace aquí evidente. El suceso extraordinario consistente en "ver la ciudad santa" es proseguido con la exégesis, que se concentra en los siguientes aspectos: en primer lugar, en su comprensión histórica, pues su aparición tiene que entenderse en relación, según el pensamiento figural tan bien estudiado por Erich Auerbach a partir

${ }^{52}$ Ibidem, p. 186; M.I. Flisfisch (ed.), Sinfonía, p. 327.

${ }^{53}$ H. of Bingen, Symphonia, p. 192; M.I. Flisfisch (ed.), Sinfonía, p. 352.

${ }^{54}$ Symphonia, p. 194; M.I. Flisfisch (ed.), Sinfonía, p. 353.

${ }_{55} \mathrm{H}$. of Bingen, Letters, vol. III, n. 373. 
del cual el Nuevo Testamento estaba ya prefigurado en el Antiguo ${ }^{56}$, con el Fiat del Génesis (Gen 1,3) por medio del cual Dios dio vida a todas las criaturas y al hombre que formó del polvo del suelo (Gen 2,7). Así la creación del universo encuentra su repetición en la aparición del cielo nuevo y de la tierra nueva que adquiere la forma de la Ciudad Santa. Es tras la desaparición del primer cielo y la primera tierra, cuando sucede la visión: $Y v i$ la ciudad santa, la nueva Jerusalén, que bajaba del cielo, de junto a Dios. El segundo aspecto que le interesa comentar es la comparación entre la nueva Jerusalén y la novia engalanada del texto apocalíptico: $Y$ vi la ciudad santa, la nueva Jerusalén, que bajaba del cielo, de junto a Dios, engalanada como una novia ataviada para su esposo. En la exégesis de Hildegard, el esposo es el Hijo de Dios; la Jerusalén, como la novia, está hecha con el derramamiento de la sangre del Hijo. En medio de la gran oscuridad, los cielos se iluminan con la sangre roja del Hijo y las puertas del Paraíso, que habían estado cerradas desde la expulsión de Adán, se abren. Jerusalén, construida con las buenas obras de la humanidad, está hecha para alabar la humanidad de Dios, del mismo modo que creó los ángeles en honor de su divinidad. En esta ciudad, dice Hildegard, Jesucristo es la piedra angular en la que se unen los muros en el tempo de la Jerusalén celeste. Sí es clara la referencia a Efesios 2,20,

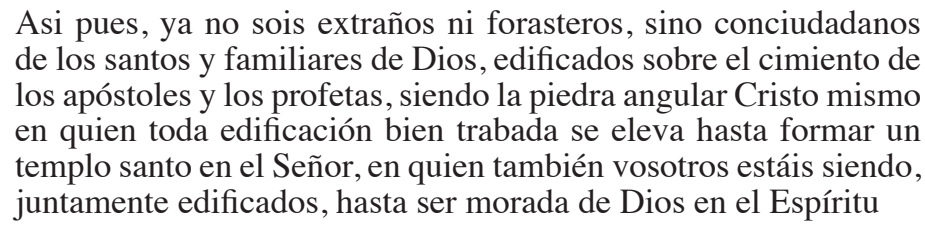

No parece menos presente en esta exégesis la visión de la ciudad celeste de la propia Hildegard. La propia experiencia, y no sólo la comprensión exegética, es lo que le permite afirmar que Todo lo que Juan vió y oyó en la divina revelación es verdad y, para terminar la carta, exhorta al destinatario a que con deseos santos y buenas obras construya el tabernáculo en la Jerusalén celeste y que la adorne, hambriento de amor a Dios, de hermosas ventanas.

${ }^{56}$ E. Auerbach, Figura. 


\section{JERUSALÉN CELESTE}

Los manuscritos de Wiesbaden o de Lucca en los que se encuentran el Scivias y el Liber divinorum operum de Hildegard han sido entendidos como obras cuya intención fundamental debió consistir en dar testimonio de sus dones visionarios y argumentar así su santificación. Sus visiones e imágenes poseyeron la función cognitiva que acostumbró a otorgarles el monasticismo del siglo XII y el neoplatonismo dominante en la filosofía de la época, la de los victorinos, en especial. En este sentido, la visión de la ciudad celeste de Hildegard es una imagen habitual en la época. Se trata de un símbolo arquitectónico proporcionado por las Escrituras como por ejemplo el arca de Noé, el templo de Ezequiel,el tabernáculo, el templo de Salomón, la torre de Babel, la casa de la sabiduría o la Jerusalén celeste, que los espirituales emplearon con frecuencia como instrumento, no sólo exegético, sino también como objeto de meditación y oración, como écfrasis destinado a una interiorización necesaria para la vida del espíritu. Anne C. Esmeijer en su libro acerca de la Divina quaternitas publicado en Amsterdam en 1978 consideraba el segundo esquema visual exegético esta cuaternidad cósmico-arquitectónica que podía remontarse a la tradición antigua de una construcción cósmica o una ciudad cósmica a partir de un cuadrado, un rectángulo o un plano circular dividido por un ortógono o una diagonal en cuatro. Destacaba Esmeijer la indecisión entre el círculo y el cuadrado. Los exégetas hicieron un uso considerable de estos símbolos arquitectónicos como el punto de partida inicial para sus interpretaciones. La ciudad de Jerusalén constituyó el tema más difundido pues resultaba ideal para desplegar los cuatro sentidos: histórico, alegórico, tropológico y anagógico. Desde Orígenes, Jerusalén fue la civitas Dei y Ecclesia, cuyo arquitecto era Cristo, y también fue entendida como lo que se construye en el corazón de cada creyente, siendo muy común esta interpretación en el primer cristianismo por la influencia del De civitate Dei de san Agustín. La Jerusalén celeste como objeto de visión, visio beatae urbis Jerusalem, correspondió a su integración en las iglesias en las que, como estudió Esmeijer, el camino del ojo estaba guiado por programas cuyo propósito principal consistía en elevar el alma, siendo la dirección no siempre vertical, sino que podía ser horizontal, en áreas que se sucedían unas detrás de otras. Por ejemplo en la iglesia de san Pietro al Monte, en la abadía benedictina de Civate que contiene pinturas atribuidas a la escuela lombarda a finales del siglo XI, los motivos extraídos del Apocalipsis pueden ser seguidos en orden cronológico, moviéndose el ojo en una dirección oriental desde el ciborio hasta el altar mayor. Se proporcionaba así una visión gradual de las manifestaciones del cielo culminando con la visión de la ciudad celeste. Las cuaternidades de los ángeles y los ríos/trompetas, son una introducción a la visión de la Ciudad 
Celestial en la bóveda delante de la puerta. La pintura crea la ilusión de la luz para seguir en sus aspectos iconográficos a Apocalipsis 21: la forma cuadrada de la ciudad, las 12 puertas y las 12 figuras; todas las puertas miran hacia dentro y en ellas hay inscripciones con los nombres de las piedras preciosas. El río fluye desde el trono fuera de la ciudad. En las cuatro esquinas se encuentran los cuatro nombres de las virtudes cardinales: iustitia, fortitudo, temperantia, prudentia. El resultado, concluye Esmeijer, es una completa exégesis visual de la interpretación múltiple de Jerusalén: histórica -la ciudad cósmica con su división cuatripartita; alegórica -la Ecclesia formada por Cristo y las piedras vivientes con las que la Ciudad está construida; tropológica -las cuatro virtudes como piedras angulares de la Jerusalén del alma humna; y analógica -la "beata visio pacis ${ }^{57}$. Por su parte Mary Carruthers, en The Craft of thought, publicado en 1998, trató del carácter ecfrástico de la Jerusalén celeste. Citaba al monje Arnobius de mediados del siglo V que en un comentario del Salmo 98 invitaba a su audiencia a contemplar la llegada del Señor y les instaba a que pintaran ante sus ojos la Jerusalén celeste: Pinge, pinge ante oculos tuos, qui haec cantas, aliquas fabricas. / .../pinge templa, pinge thermas. Concluía que Arnobius consideraba la descripción de Juan de la Ciudad Celeste como un caso de écfrasis, enormemente expandido (y combinado con la ciudadela de la montaña de Ezequiel) en la pintura contemplativa de su mente y memoria, y que invitaba a su audiencia a fabricar en sus mentes la descripción textual, incluyendo elementos que no se encontraban ni en Juan ni en Ezequiel ${ }^{58}$. Pero Mary Carruthers no sólo trata del écfrasis como la visualización de un texto, sino que da entrada al écfrasis en pintura (ekphrasis in paint). Así por ejemplo considera que la "Ciudad Celeste" del Beato Facundus es un artefacto que compromete socialmente a un diálogo meditativo a través de los colores y las formas de todas sus imágenes ${ }^{59}$. Descripciones textuales para ser visualizadas interiormente o pintadas efectivamente en los manuscritos; imágenes plásticas para ser contempladas e interiorizadas; visiones descritas y también pintadas. Memorización, visualización, meditación, oración: éstas son las funciones de imágenes y textos combinados de múltiples formas. El caso de Hugo de san Victor, estudiado con gran precisión por Patrice Sicard, en un libro publicado en 1993, resulta ejemplar para comprender el valor de las imágenes en el ámbito monástico del siglo XII. En el prólogo al De archa se describe a la comunidad monástica sentada en el claustro o capítulo, donde tenía lugar la reunión para el intercambio de ideas y formulación de cuestiones a las que

57 A.C. Esmeijer, Divina Quaternitas, p. 79.

${ }_{58}$ M. Carruthers, The craft, p. 135.

${ }^{59}$ Ibidem, p.223. 
respondía el maestro. En estas collationes, o conferencias espirituales ante un auditorio silencioso, encontró su origen los tratados acerca del Arca de Noé como símbolo arquitectónico. El maestro en exégesis que era Hugo no sólo hablaba, sino que las representaciones figuradas desempeñaban también un papel esencial: Huius uero spiritualis edificio exemplar tibi dabo archam Noe, quam foris uidebit oculus tuus, ut ad eius similitudinem intus fabricetur animus tuus ${ }^{60}$. Sicard interpreta De archa (fechado en 1126) como la exposición discursiva de lo que el Libellus (de 1129) proporciona como forma figurada, y supone la existencia de un gran dibujo, probablemente sobre el pavimento del claustro más que sobre un pergamino, que habría sido realizado durante la misma expresión oral, en una simultaneidad entre palabra y acción. No es posible pensar en este contexto en la creación de una imagen como sustituta de un texto para un público de iletrados, sino que incluso puede pensarse en la superioridad de la imagen frente al texto dado su mayor proximidad con respecto al arquetipo según la teoría platónica. Algunos años más tarde, Ricardo de san Víctor en su Comentario a la visión del templo de Ezequiel reconstruyó su apariencia, a diferencia del papa Gregorio el Grande quien consideró que era esa una tarea imposible, dado que Ezequiel no trataba de proyectar una imagen de una estructura coherente y tangible, sino que se refería a un edificio espiritual y no material (quasi aedificium). Así, en el códice de saint Victor, fechado hacia el año 1170, se encuentran trece ilustraciones que fueron repetidas en diez manuscritos, y si no fue el mismo Richard quien las realizara, parece en cambio seguro que las debió supervisar ${ }^{61}$.

Los ejemplos mencionados pueden ser confrontados con la ciudad celeste de Hildegard. Si a diferencia del caso de Hugo de san Víctor, en la obra deHildegard noencontramos indicaciones suficientes acerca del modoen que debían ser utilizadas las imágenes, no considero descabellado situarlas dentro del mismo contexto que condujo a introducir en las iglesias imágenes de la Jerusalén celeste o el de los victorinos, que elevaron la función de la imagen por encima de la palabra. La interiorización de las imágenes como un ejercicio del alma, su meditación para la construcción del templo interior parece estar en el fundamento de la exposición de sus visiones y de su reunión en los manuscritos, de su ilustración y difusión. La descripción de la visión de la ciudad en Scivias constituye una actualización de la visión de la Jerusalén celeste por parte de Juan de Patmos y su objetivo era con toda probabilidad que la comunidad monástica "la pintara" en su interior, oyendo las palabras y viendo las miniaturas. Estimular a la contemplación de la ciudad celeste, la propia, la que

${ }^{60}$ De archa, I, iii, 35-37, citado por P. Sicard, Diagrammes médiévaux, p. 34.

${ }^{61}$ W. Cahn, Architectural Draftsmanship . 
nace en la interioridad de cada uno de los oyentes, al tiempo que penetrar en el significado de la construcción de la obra colectiva que es la Jerusalén celeste, ésa debió de ser la función de la tercera parte de Scivias.

\section{SIMBOLISMO DEL MANDALA}

Como conclusión, me gustaría dar entrada a una breve reflexión acerca de la visión de la ciudad celeste desde la perspectiva de nuestro mundo. En mis estudios sobre Hildegard von Bingen he tratado de comprender su experiencia visionaria comparándola con los procesos creativos de artistas del siglo XX, en particular con aquellos cuya pintura ha podido surgir desde una pasividad y a la espera de la floración de las imágenes ${ }^{62}$. De esto modo, la visión en la Edad Media habitualmente interpretada por la crítica de nuestro mundo como una estrategia para dar entrada a la expresión alegórica, adquiría una inusitada autenticidad, pues testimonios de artistas como Max Ernst, René Magritte o Joan Miró diluían la alteridad de tal experiencia ofreciendo nuevas posibilidades de comprensión. La reciente publicación de El libro rojo de Carl Gustav Jung proporciona, a mi modo de ver, nuevos materiales de confrontación con la experiencia mística y visionaria de la Edad Media. El psiquiatra suizo, alertado por una alucinación que le sucedió en otoño de 1913, se dispuso desde ese mismo año a realizar lo que él mismo denominó el encuentro con el inconsciente. La noche, cuando tiene lugar la introversión de la libido, le pareció el tiempo idóneo para dicho encuentro. Así, este penseur de la nuit como le llamó Yves Bonnefoy, junto a William Blake, Kafka, y otros, realizó un experimento que habría de durar más de una década y que habría de constituir el núcleo de toda su posterior investigación teórica. Las fantasías, como él las denominaba, es decir, imágenes repentinamente aparecidas en su psique, que habrían de ir adquiriendo un progresivo despliegue en historias con figuras que mantenían diálogos, fueron rigurosamente transcritos en los cuadernos negros que luego habrían de trasladarse al gran formato de El libro rojo, donde además fueron ilustrados. El método de la imaginación activa, tal y como luego fue bautizado en sus prácticas terapéuticas, constituyó el fundamento para la realización del libro. Sólo algunas alusiones en sus memorias autobiográficas recogidas por su discípula Aniela Jaffé, Recuerdos sueños y pensamientos, atestiguaron la existencia de este libro rojo o liber novus, como también lo denominó Jung en la medida en que toda mirada a la interioridad es necesariamente una mirada nueva, realizado

${ }^{62}$ V. Cirlot, Hildegard von Bingen y la tradición; V. Cirlot, La visión abierta. 
a modo de un manuscrito medieval, pues permaneció en la más estricta privacidad hasta hace sólo dos años, cuando en 2009 fue publicado en edición facsímil por la editorial Norton de Nueva York. Me interesan ahora sólo dos ilustraciones de El libro rojo que se encuentran en la parte segunda, en las páginas 105 y 163 (Fig. 20 y 21).

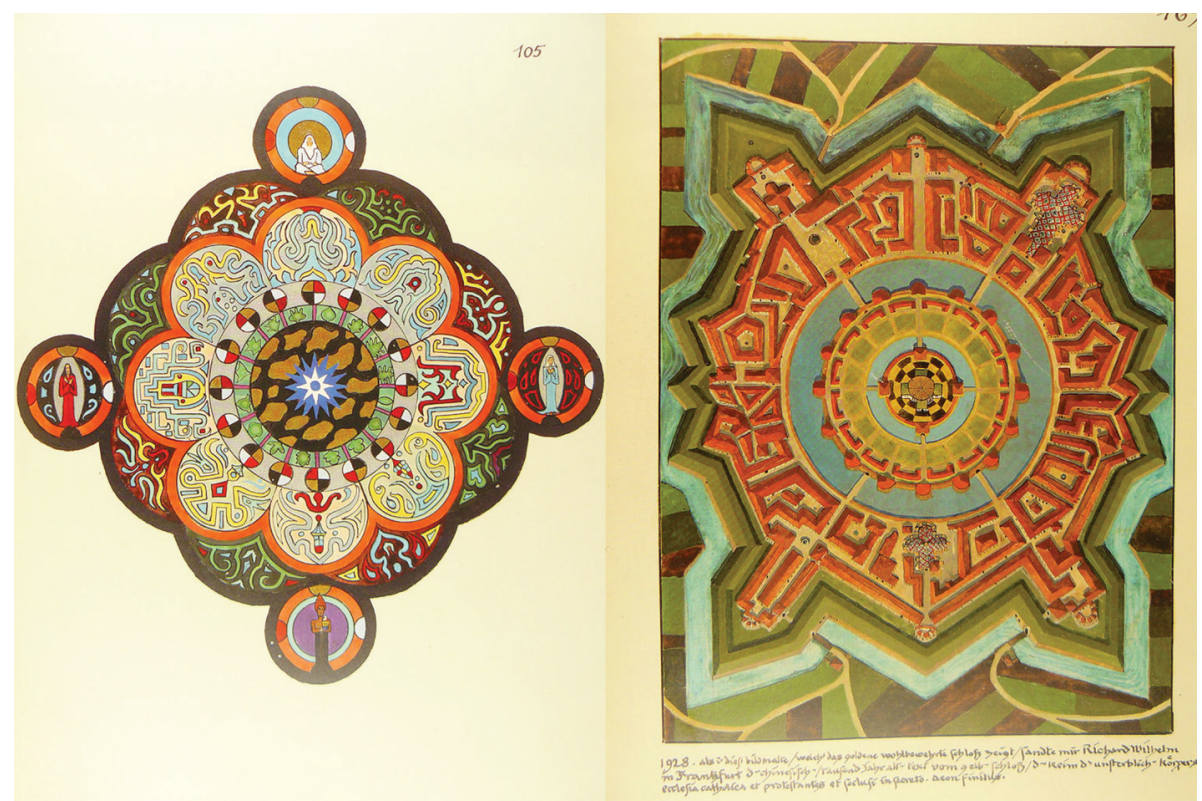

Figs. 20-21. Carl Gustav Jung, El libro rojo, pp. 105 y 163, año 1928.

Se encuentran estrechamente relacionadas con la serie de mandalas que ocupan un lugar destacado en esta parte del libro y no poseen una relación explícita con el texto. La imagen 105 fue introducida por Jung en el Comentario al libro El secreto de la flor de oro de 1929. Jung describió la imagen del siguiente modo ${ }^{63}$ :

En el medio brilla la luz blanca en el firmamento. En el primer círculo: semillas de vida protoplasmáticas; en el segundo: principios cósmicos que rotan, los cuales contienen los cuatro colores fundamentales; en el tercero y el cuarto: fuerzas creadoras que actúan hacia dentro y hacia fuera. En los puntos cardinales:

${ }^{63}$ Citado en C.G. Jung, El libro rojo, p. 296. 
las almas, masculina y femenina, divididas de nuevo según brillante y oscura.

En 1952 volvió a reproducir esta imagen en Sobre el simbolismo del mandala y comentó:

El cuadro es obra de un hombre de mediana edad. En el centro hay una estrella. El cielo azul contiene nubes doradas. En los cuatro puntos cardinales vemos figuras humanas: arriba, un viejo en actitud de contemplación, y abajo, Loki o Hefestos con llameantes cabellos rojos y con un templo en la mano. A la derecha y a la izquierda, de pie, dos figuras femeninas, una oscura y otra de color claro. Con ellos quedan indicados cuatro aspectos de la personalidad, o cuatro figuras arquetípicas que pertenecen, por así decir, a la periferia del sí mismo.

La siguiente imagen, la de la página 163 contiene al pie un pequeño texto que dice: 1928. Cuando dibujé esta imagen que muestra el castillo dorado bien fortificado, Richard Wilhelm me envió de Frankfurt el milenario texto chino del castillo amarillo, el embrión del cuerpo inmortal. En el Comentario al libro de El secreto de la flor de oro ${ }^{64}$ describió la imagen como:

un mandala como una ciudad fortificada con muro y acequia. Dentro una amplia acequia rodea un muro fortificado provisto de 16 torres y otra acequia interior que la sigue. Esta acequia encierra un castillo central con techos de oro cuyo centro es un templo de oro.

La volvió a reproducir en 1952 en Sobre el simbolismo del mandala ${ }^{65}$ y comentó:

Representación de una ciudad medieval, con murallas y fosos, calles e iglesias, todo ordenado en cuatro radios. La ciudad interior está rodeada a su vez de murallas y fosos, de modo parecido a la ciudad imperial de Pekín. Los edificios se abren todos hacia el centro, que está representado por un palacio de techos dorados. También está circundado por un foso (...) y continúa diciendo: Un cuadro así no es ajeno a la simbólica cristiana. La Jerusalén celestial, en el Apocalipsis, es conocida por todos. También el mundo de imágenes de la India conoce la ciudad de Brahman, en el Meru, el monte del mundo.

En Recuerdos, sueños y pensamientos, Jung se refiere de nuevo a esta última imagen ${ }^{66}$ :

${ }^{64}$ Ibidem, p. 321.

${ }^{65}$ Ibidem, p. 321.

${ }^{66}$ C.G. Jung, Recuerdos, p. 204. 
Una confirmación del pensamiento sobre el centro y el uno mismo la obtuve años más tarde (1927) por medio de un sueño. Su esencia la presenté en un mandala al definirlo como "ventana a la eternidad". El dibujo está reproducido en El secreto de la flor de oro. Un año después hice otro dibujo, igualmente un mandala en cuyo centro había un castillo dorado. Cuando estuvo terminado me pregunté: “¿Por qué he hecho esto tan chinesco?” (...) Fue una rara coincidencia recibir poco después una carta de Richard Wilhelm. Me enviaba el manuscrito de un tratado taoísto-alquímico chino con el título Das Geheimnis del Goldenen Blüte y me rogaba que lo comentara. Leí rápidamente el texto, pues aportaba una insospechada confirmación a mis ideas sobre el mandala y el movimiento circular alrededor del centro (...) También el sueño que tuve en 1927 y al que me he referido representaba un mandala: Me hallaba en una ciudad, sucia, llena de hollín. Llovía y todo era oscuro, era invierno y de noche (...) Los barrios de la ciudad eran radiales y tenían por centro a esta plaza. En el centro se hallaba un estanque redondo y en su interior una pequeña isla central. Mientras todo estaba cubierto por la lluvia, la niebla, el humo y la noche escasamente iluminada, la pequeña isla resplandecía a la luz del sol. Allí había un árbol solitario, un magnolio recubierto de flores rojas. Era como si el árbol estuviese al sol y a la vez fuera luz.

El sueño de Jung que dio lugar a las imágenes que vemos y que él mismo relacionó con el arquetipo de la Jerusalén celeste, fue interpretado como la representación de su situación de aquella época, como una imagen acabada, en la que destacaba el centro como sede de la vida. El lenguaje psicológico, con el individualismo y la subjetividad que lo caracterizan, sustituye aquí al lenguaje metafísico de Hildegard von Bingen. Como él mismo sostuvo en su Comentario al Misterio de la Flor de oro, el texto resulta incomprensible desde un punto de vista metafísico, pero no psicológico. Esta traducción no supone, sin embargo, el olvido del símbolo original, sino que por el contrario otorga nueva vida a lo que podría pertenecer a un pasado irremediablemente muerto.

\section{BIBLIOGRAFÍA CITADA}

Auerbach, Erich, Figura, Madrid, Trotta, 1998.

Boespflug, François; Zaluska, Yolanta, Le dogme trinitaire et l'essor de son iconographie en Occident de l'époque carolingienne au IVe Concile du Latran (1215), "Cahiers de civilisation médiévale" 37 (1994), pp. 181-240.

Cahn, Walter, Architectural Draftmanship in Twelfth-Century Paris: The Illlustrations of Richard of Saint-Victor's Commentary on Ezekiel's Temple Vision, "Gesta” 15/1-2 (1976), pp. 247-254. 
Calderoni Masetti, Anna Rosa; Dalli Regoli, Gigetta, Sanctae Hildegardis Revelationes. Manoscritto 1942, Lucca, Cassa di Risparmio, 1973.

Carruthers, Mary, The craft of thought. Meditation, Rhetoric, and the Making of Images, 400-1200, Cambridge, Cambridge University Press, 1998.

Cirlot, Victoria, Hildegard von Bingen y la tradición visionaria de Occidente, Barcelona, Herder, 2005.

Cirlot, Victoria, La visión abierta. Del mito del grial al surrealismo, Madrid, Siruela, 2010.

Corbin, Henry, Cuerpo espiritual y tierra celeste, Madrid, Siruela, 1996.

Dronke, Peter, The Symbolic Cities of Hildegard of Bingen, "The Journal of Medieval Latin" 1 (1991), pp. 168-182.

Dronke, Peter, Las escritoras de la Edad Media, Barcelona, Crítica, 1994.

Esmeijer, Anna, C., Divina Quaternitas. A preliminary study in the method and application of visual exegesis, Amsterdam, Gorcum, 1978.

Evans, Michael, The geometry of mind, "Architectural Association Quaterly" 12 (1980), pp. 32-55.

Haas, Alois Maria, Sueño y visión en la mística alemana, en Haas, A.M., Visión en azul. Estudios de mística europea, Madrid, Siruela, 1999, pp. 13-31.

Heydenreich, Ludwig, H., Ein Jerusalem-Plan aus der Zeit der Kreuzfahrer, "Miscellanea pro Arte" (1965), pp. 83-90.

Hildegard of Bingen, Symphonia. A critical edition of the Symphonia armonie celestium revelationum, ed. de de Barbara Newman, Ithaca, Cornell University Press, 1988.

Hildegard von Bingen, Vida y visiones, ed. de Victoria Cirlot, Madrid, Siruela, 2009.

Hildegard of Bingen, The Letters of Hildegard of Bingen, 3 vols., ed. de Joseph L. Baird, Radd K. Ehrman (ed.), Nueva York - Oxford, Oxford University Press, 1994-2004.

Hildegarda de Bingen, Scivias: conoce los caminos, Antonio Castro Zafra, Mónica Castro (trad.), Madrid, Trotta, 1999.

Hildegarda de Bingen, Libro de las obras divinas, ed. de María Isabel Flisfisch, María Eugenia Góngora, María José Ortúzar, Barcelona, Herder, 2009.

Hildegardis Bingensis, Liber Divinorum operum, Albert Derolez, Peter Dronke (eds.), Turnhout, Brepols, 1996. (Corpus Christianorum Continuatio Mediaevalis; 92).

Hildegardis Bingensis, Scivias, edición de Adelgundis Führkötter con la colaboración de Angela Carlevaris, Turnhout, Brepols, 1978. (Corpus Christianorum Continuatio Mediaevalis; 43).

Ildegarda di Bingen, Il libro delle opere divine, Marta Cristiani, Michela Pereira (eds.), Milán, Mondadori, 2003. 
Jung, Carl Gustav, Recuerdos, sueños, pensamientos, Barcelona, Seix Barral, 1966.

Jung, Carl Gustav, El Libro Rojo, edición alemana de Sonu Shamdasani; edición castellana al cuidado de Bernardo Nante, Buenos Aires, El Hilo de Ariadna - Malba, Fundación Costantini, 2010.

Lewis, Suzanne, Reading Images. Narrative Discourse and Reception in the thirteenth-century Illuminated Apocalypse, Cambridge, Cambridge University Press, 1995.

Riedel, Ingrid, Hildegards Sophia-Vision. Zu einer Miniatur aus dem LuccaKodex, en Forster, Edeltraud (ed.), Hildegard von Bingen, Prophetin durch die Zeiten. Zum 900. Geburtstag, Friburgo de Brisgovia, Herder, 1997, pp. 406-418.

Saurma-Jeltsch, Lieselotte E., Die Miniaturen im "Liber Scivias" der Hildegard von Bingen, Wiesbaden, Reichert Verlag, 1998.

Scholem, Gershom, Las grandes tendencias de la mística judía, Madrid, Siruela, 1996.

Schmitt, Jean-Claude, Hildegard von Bingen oder die Zurückweisung des Traums, en Haverkamp, Alfred (ed.), Hildegard von Bingen in ihrem historischen Umfeld, Maguncia, Philipp von Zabern, 2000, pp. 351373.

Sicard, Patrice, Diagrammes médiévaux et exégèse visuelle. Le Libellus de formatione arche de Hugues de Saint-Victor, Turnhout, Brepols, 1993.

Fecha de recepción del artículo: octubre 2013

Fecha de aceptación y version final: marzo 2014 